\title{
Elaboration of Lamellar and Nanostructured Materials Based on Manganese: Efficient Adsorbents for Removing Heavy Metals
}

\author{
Amina Amarray, ${ }^{1 *}$ Sanae El Ghachtouli, ${ }^{1 *}$ Mohammed Ait Himi, ${ }^{1}$ \\ Mohamed Aqil, ${ }^{2}$ Khaoula Khaless, ${ }^{3}$ Younes Brahmi, ${ }^{2}$ Mouad Dahbi ${ }^{2}$ \\ and Mohammed Azzi ${ }^{1}$ \\ ${ }^{1}$ Laboratoire Interface Matériaux - Environnement, Faculté des Sciences Ain-Chock, Université Hassan II de Casablanca, \\ B.P 5366 Maarif, Casablanca, Maroc. \\ ${ }^{2}$ Materials Science and Nano-engineering Department, Mohammed VI Polytechnic University (UM6P), \\ Ben Guerir, Morocco. \\ ${ }^{3}$ Department of Chemical and Biochemical Sciences, Green Process Engineering CBS. Mohammed VI Polytechnic University, \\ Ben Guerir, Morocco. \\ *Corresponding author: E-mail: s.elghachtouli@gmail.com.
}

Received: 04-25-2020

\begin{abstract}
The lamellar and nanostructured manganese oxide materials were chemically synthesized by soft and non-toxic methods. The materials showed a monophasic character, symptomatic morphologies, as well as the predominance of a mesoporous structure. The removal of heavy metals $\mathrm{Cd}(\mathrm{II})$ and $\mathrm{Pb}(\mathrm{II})$ by the synthesized materials $\mathrm{Na}-\mathrm{MnO}_{2}, \mathrm{Urchin}^{-\mathrm{MnO}_{2}}$ and Cocoon- $\mathrm{MnO}_{2}$ according to the mineral structure and nature of the sites were also studied. Kinetically, the lamellar manganese oxide material $\mathrm{Na}-\mathrm{MnO}_{2}$ was the most efficient of the three materials which had more vacancies in the $\mathrm{MnO}_{6}$ layers as well as in the space between the layers. The nanomaterials Urchin- $\mathrm{MnO}_{2}$ and Cocoon- $\mathrm{MnO}$ could exchange with the metal cations in their tunnels and cavities, respectively. The maximum adsorbed quantities followed the order ( $\mathrm{Pb}(\mathrm{II}): \mathrm{Na}-\mathrm{MnO}_{2}(297 \mathrm{mg} / \mathrm{g})>$ Urchin- $\mathrm{MnO}_{2}$ (264 mg/g) >Cocoon-MnO (209 mg/g), Cd(II): Na-MnO 2 (199 $\mathrm{mg} / \mathrm{g})>$ Urchin $\left.-\mathrm{MnO}_{2}(191 \mathrm{mg} / \mathrm{g})>\mathrm{Cocoon}-\mathrm{MnO}_{2}(172 \mathrm{mg} / \mathrm{g})\right)$. Na- $\mathrm{MnO}_{2}$ material exhibited the best stability among the different structures, $\mathrm{Na}-\mathrm{MnO}_{2}$ presented a very low amount of the manganese released. The results obtained showed the potential of lamellar manganese oxides $\left(\mathrm{Na}-\mathrm{MnO}_{2}\right)$ and nanostructures $\left(\mathrm{Urchin}-\mathrm{MnO}_{2}\right.$ and Cocoon- $\mathrm{MnO}$ ) as selective, economical, and stable materials for the removal of toxic metals in an aqueous medium.
\end{abstract}

Keywords: Cadmium; lead; Wastewater; manganese oxide; kinetic; mesoporous structure

\section{Introduction}

The depletion of drinking water resources had been a global problem in recent years, due to water pollution by heavy metals mainly from intensive human activities. These pollutants were not biodegradable and toxic. ${ }^{1}$ Moreover, all along the food chain, some of them were concentrated in living organisms, which posed major risks to the environment and human health. ${ }^{2-4}$ This contamination was certainly the most serious case among the problems posed by environmental pollution..$^{5-7}$ Metal ions were more precisely cadmium and lead were general- ly released without appropriate treatment during industrial processes, ${ }^{8,9}$ such as in metal factories, paint industries, battery production as well in the combustion of motor gasoline (lead), etc... Lead and cadmium were persistent metals in the subsoil. Consequently, lead contamination of soil and groundwater was a serious problem. ${ }^{10}$ Exposure to $\mathrm{Pb}(\mathrm{II})$ and as it was known worldwide could damage the nervous system and be carcinogenic to humans. ${ }^{11-14}$ It could also damage the kidneys, cellular processes, and the reproductive system. ${ }^{15}$ Toxic symptoms could occur in several ways, such as anemia, insomnia, headaches, muscle weakness, hallucinations, and kidney 
damage. ${ }^{16}$ The United States Environmental Protection Agency had classified cadmium as a probable human carcinogen. ${ }^{17}$ Chronic exposure to cadmium posed serious risks, including kidney dysfunction and high levels of exposure leading to death. ${ }^{18}$ Environmental requirements were becoming increasingly stringent in the paint industry, as for all industrial activities.

Intensive research and development efforts were being used worldwide to develop effective processes to reduce or eliminate toxic metal ions in aqueous solutions using precipitation of several metals such as lead, ${ }^{19}$ cadmium ${ }^{20}$ and magnesium. ${ }^{21}$ Still, they provided that this process was carried out at a pH between 8 and $11 .^{18,22}$ Others have used polyamide membranes to remove $\mathrm{Cd}(\mathrm{II})^{23}$ and $\mathrm{Cu}(\mathrm{II})^{24}$ cations by reverse osmosis. Other processes had adopted elaborate materials such as zeolite, ${ }^{25,26}$ which had been used as an adsorbent to remove some heavy metals, but with adequate pretreatment systems for suspended solids removal before applying ion exchange. However, the application of these methods was limited due to their high energy costs, their complex operation and equipment, their secondary pollution, and the problem of regeneration. The adsorption technique had proven to be the most efficient process due to its simplicity, ease of implementation, and high efficiency over a wide range of concentrations. ${ }^{27}$ Additionally, it was a cost-effective method for treating large quantities of wastewater containing low levels of pollutants. ${ }^{28}$ Unlike many techniques based on oxidation/reduction reactions or photocatalytic reactions, adsorption remained a method that does not lead to the formation of products/by-products that may be more or less toxic, or that subsequently caused secondary contamination. For this purpose, several types of adsorbents had been used, either synthetic ${ }^{29,30}$ or natural such as calcium hydroxyapatite (CaHAP) ${ }^{31}$ and barium hydroxyapatite (BaHAP), ${ }^{32}$ perlite which has been used to remove cadmium and nickel ions in the aqueous medium. ${ }^{33}$ Peat, ${ }^{34}$ carbon nanotubes, ${ }^{35}$ alumina, ${ }^{36}$ mesoporous silica, ${ }^{37}$ and clays $^{38,39}$ had also been applied to remove or reduce some heavy metals at different concentrations. However, these adsorbents had several disadvantages. They were characterized by their low adsorption capacity, reactivity and long equilibrium time to remove heavy metals. ${ }^{40-42}$

The manganese oxides materials existed widely in a large variety of forms in the upper crust. They were very important minerals because of their abundance and high reactivity. They were the strongest oxides in soils and were characterized by high sorption power. ${ }^{43}$ They had a high capacity to remove several organic pollutants from soils and sediments. ${ }^{44}$

In general, manganese oxides materials were characterized by a low point of zero charge (PZC), ${ }^{45}$ a relatively large surface area, and strong acid sites, which gave them a high adsorption capacity and excellent oxidation and catalysis activity. ${ }^{46}$ Moreover, the layered manganese oxide structure (lamellar structure) was used as an effective adsorbent to remove several heavy metals. ${ }^{47}$ These materials had a variable number of octahedral cationic vacancies within the $\mathrm{MnO}_{6}$ layers, which were important and significant adsorption sites for metal cation. ${ }^{48}$ The $\mathrm{MnO}_{6}$ layers in this type of structure were assembled in the form of sandwiches separated from each other to form spaces of $7 \AA$ (birnessite) or $10 \AA$ (buserite), this generated a large part of the sorption sites. ${ }^{49}$ Tunnel structures were generally made up of single, double or triple chains that were connected by their vertices to form tunnels of square or rectangular cross-section with inserted cations $\left(\mathrm{H}^{+}\right.$or $\left.\mathrm{K}^{+}\right){ }^{50}$

The use of this type of material to remove metal cations was favorable and generally carried out by ion charge equilibrium exchange with cations inserted in tunnels that were characterized by a space of $4.6 \AA .^{51}$ The removal of several metals, including arsenic (III) and (V) from aqueous medium, had been studied using materials based on manganese with a compact structure (hausmannite). ${ }^{52}$ Various studies had been carried out to remove several metals such as copper, ${ }^{53}$ nickel, ${ }^{54,55}$ lead, ${ }^{56,57}$ cadmium $^{27}$ and zinc ${ }^{58}$ ions using iron and modified manganese oxides as adsorbents. A research study reported that despite the high reactivity of iron oxides, the manganese oxides had shown an efficiency 40 times higher than iron oxides in the case of $\mathrm{Pb}$ (II) ions. ${ }^{59}$ Indeed several studies have shown that the use of manganese oxides for the coating of some materials such as biochar (BC) ${ }^{60}$ wool, ${ }^{61}$ and zeolite, ${ }^{62}$ allowed to increase their specific surface as well as the volume of the pores and consequently to favor the adsorption phenomenon. This showed the very important role of manganese oxides for the removal of metal ions from aqueous medium.

In this work, we investigated the possibility of removing $\mathrm{Pb}(\mathrm{II})$ and $\mathrm{Cd}(\mathrm{II})$ ions from the aqueous medium by three manganese oxide materials (marked as $\mathrm{Na}-\mathrm{MnO}_{2}$, Urchin- $\mathrm{MnO}_{2}$, and Cocoon- $\mathrm{MnO}_{2}$ ) with different lamellar structures and nanostructures. The composition, morphology, and distribution of the sites of each material were determined by different spectroscopic techniques. To better understand the removal process of $\mathrm{Pb}$ (II) and $\mathrm{Cd}(\mathrm{II})$ by manganese oxides materials, the effect of $\mathrm{pH}$, kinetics and adsorption studies were examined. To study the stability of the materials, the total amount of manganese released during removal processes will be elucidated. These materials will be characterized by X-ray diffraction after interaction. To verify the reusability of the materials for the removal of $\mathrm{Pb}$ (II) and $\mathrm{Cd}(\mathrm{II})$, five successive cycles were performed, as well as examining their stability.

To better understand the removal process of $\mathrm{Pb}$ (II) and Cd(II) by manganese oxides materials the performing kinetic and adsorption studies were examined. Finally, these materials will be characterized after the interaction by X-ray diffraction. To study the stability of the materials, 
the total amount of manganese released, and the amount of heavy metal removed will be elucidated.

\section{Experimental Section}

\section{1. Chemical Compounds}

All chemicals used in this study were purchased from Sigma Aldrich (St. Louis, MO, USA) and were used without further purification. Solutions were prepared with demineralized water from the Adrona crystal water system (quality $\leq 0.05 \mu \mathrm{S} / \mathrm{cm}$ ).

\section{2. Synthesis of $\mathrm{Na}-\mathrm{MnO}_{2}$}

Manganese oxide $\mathrm{Na}-\mathrm{MnO}_{2}$ was obtained by precipitation at room temperature. During stirring, $10 \mathrm{~mL}$ of hydrogen peroxide mixed with $2.16 \mathrm{~g}$ of sodium hydroxide dissolved in $90 \mathrm{~mL}$ of water was added dropwise to the manganese sulfate solution $\left(\mathrm{MnSO}_{4} \cdot \mathrm{H}_{2} \mathrm{O}\right)(2.535 \mathrm{~g}$, $50 \mathrm{~mL}$ ). The mixture remained agitated overnight at room temperature. The deep brown precipitate obtained after filtration was washed with water and ethanol. The product was recovered by filtration and dried at $50{ }^{\circ} \mathrm{C} .{ }^{63}$

\section{3. Synthesis of Urchin- $\mathrm{MnO}_{2}$ Nanostructure}

Urchin manganese oxide $\mathrm{MnO}_{2}$ nanostructure was synthesized by the reflux method under acidic conditions. ${ }^{64} 2 \mathrm{~g}$ of manganese sulfate $\left(\mathrm{MnSO}_{4} \cdot \mathrm{H}_{2} \mathrm{O}\right)$ was dissolved in $100 \mathrm{~mL}$ of distilled water. In a water bath and under vigorous stirring, $1 \mathrm{~mL}$ of sulfuric acid was added by dripping. After stirring, $66 \mathrm{~mL}$ of potassium permanganate $(0.1 \mathrm{M})$ was added to the mixture. Stirring was maintained at $80^{\circ} \mathrm{C}$ for 24 hours. The resulting black colored product was isolated and washed several times with water and absolute ethanol. Finally, the product obtained was dried at $60^{\circ} \mathrm{C}$.

\section{4. Synthesis of Cocoon- $\mathrm{MnO}_{2}$ Nanostructures}

Synthesis of manganese oxide type cocoon was based on the reduction of $\mathrm{Mn}$ (VII) and $\mathrm{Mn}$ (II) under ambient temperature conditions. ${ }^{64} 100 \mathrm{~mL}$ of potassium permanganate $\mathrm{KMnO}_{4}$ solution $(0.1 \mathrm{M})$ was added dropwise under vigorous agitation to $150 \mathrm{~mL}$ of manganese sulfate solution $(0.1 \mathrm{M})$. The resulting mixture was agitated for 6 hours. The resulting black colored product was isolated, washed several times with water and absolute ethanol, and dried at $60^{\circ} \mathrm{C}$.

\section{5. Chemical Analysis}

The chemical composition of the three materials was determined by dissolving $0.1 \mathrm{~g}$ of sample with $1 \mathrm{~g}$ of hy- droxylamine hydrochloride in $250 \mathrm{~mL}$ of the distilled water. ${ }^{65}$ The resulting $\mathrm{Mn}, \mathrm{K}$, and $\mathrm{Na}$ content in the solution was determined by atomic absorption spectrometry device (Shimadzu AA-7000) (Shimadzu Corporation, Japon).

Manganese average oxidation state (AOS) was determined by potentiometric determination using sodium pyrophosphate. This method avoids errors related to mass and reagent concentration measurements, and the only parameters to be determined were equivalent volumes. ${ }^{66}$ All chemical analysis was repeated three times, and the average was determined.

\subsection{Characterization}

$\mathrm{X}$-ray diffraction patterns were recorded on a Bruker D8 (Bruker, France S.A.S). Advance diffractometer equipped with a graphite monochromator, a Lynx-Eye detector, and parallel beam optics using $\mathrm{Cu}$ Ka radiation $(\lambda=$ $1.5418 \AA$ A). Phase identification and material structures were determined by the High Score software (XRD data processing software).

The morphology of the particles of the various synthesized samples was studied by scanning electron microscopy (JEOL Ltd Gemini 15-25, Japon).

The specific surface area analysis was performed using the Brunauer-Emmett-Teller (BET) method and the pore size distribution was determined using the BarrettJoyner-Halenda (BJH) method from $\mathrm{N}_{2}$ adsorption and desorption isotherms using Micromeritics Gemini VII system (Micromeritics Instruments Corporation, USA). $0.1 \mathrm{~g}$ of the sample was degassed before measurement at $110^{\circ} \mathrm{C}$ for 3 hours under vacuum equilibrium.

\section{7. Batch Experiment of $\mathrm{Cd}(\mathrm{II})$ and $\mathrm{Pb}(\mathrm{II})$ Removal}

The $\mathrm{Cd}(\mathrm{II})$ and $\mathrm{Pb}(\mathrm{II})$ ions removal experiments were performed by placing $100 \mathrm{mg}$ of the synthesized material in a $50 \mathrm{~mL}$ of an aqueous solution containing 30 ppm of the $\mathrm{Cd}(\mathrm{II})$ or $\mathrm{Pb}(\mathrm{II})$ respectively as $\mathrm{Cd}\left(\mathrm{NO}_{3}\right)_{2}$ or $\mathrm{Pb}\left(\mathrm{NO}_{3}\right)_{2}$. The content was agitated $(500 \mathrm{rpm})$ during the interaction. The metal cation removal experiments were performed under ambient conditions at different values of $\mathrm{pH}$. The solution $\mathrm{pH}$ was adjusted using $\mathrm{NaOH}$ $(0.1 \mathrm{M})$ or $\mathrm{H}_{2} \mathrm{SO}_{4}(0.1 \mathrm{M})$. The solution was filtered through a $0.45 \mu \mathrm{m}$ membrane, and the residual concentration of the metal cation $\mathrm{Cd}(\mathrm{II})$ and $\mathrm{Pb}$ (II) concentration in the solution was analyzed using atomic absorption spectrophotometer (AAS). This allowed us to evaluate the removal efficiency of heavy metal (R\%) using Eq. (1) and the adsorbed amount $\mathrm{q}(\mathrm{t})$ in $\mathrm{mg} / \mathrm{g}$ using Eq. (2). Measurements under the same conditions were proceeded three times.

$$
\mathrm{R}(\%)=\left(1-\frac{\mathrm{C}_{\mathrm{r}}}{\mathrm{C}_{0}}\right) \times 100
$$


$\mathrm{q}(\mathrm{t})=\frac{\left(\mathrm{C}_{0}-\mathrm{C}_{\mathrm{r}}\right) \mathrm{xV}}{\mathrm{m}}$

Where: m: mass of manganese oxide material (100 $\mathrm{mg})$.

$\mathrm{V}$ : Volume of the solution used $(50 \mathrm{~mL})$.

$\mathrm{C}_{0}$ and $\mathrm{C}_{\mathrm{r}}$ were the initial and residual concentrations of metal ions (cadmium or lead).

\section{Results and Discussion}

\section{1. $\mathrm{XRD}$ of $\mathrm{MnO}_{2}$ Lamellar and Nanostructures}

The diffractograms (Figure 1) of the synthesized manganese oxides, namely: $\mathrm{Na}-\mathrm{MnO}_{2}$, Cocoon- $\mathrm{MnO}_{2}$, and Urchin- $\mathrm{MnO}_{2}$, showed that materials were different and therefore, they don't had the same crystalline structure.

The diffractogram of the Cocoon- $\mathrm{MnO}_{2}$ material (Figure 1) had a very low-intensity signal. This could be

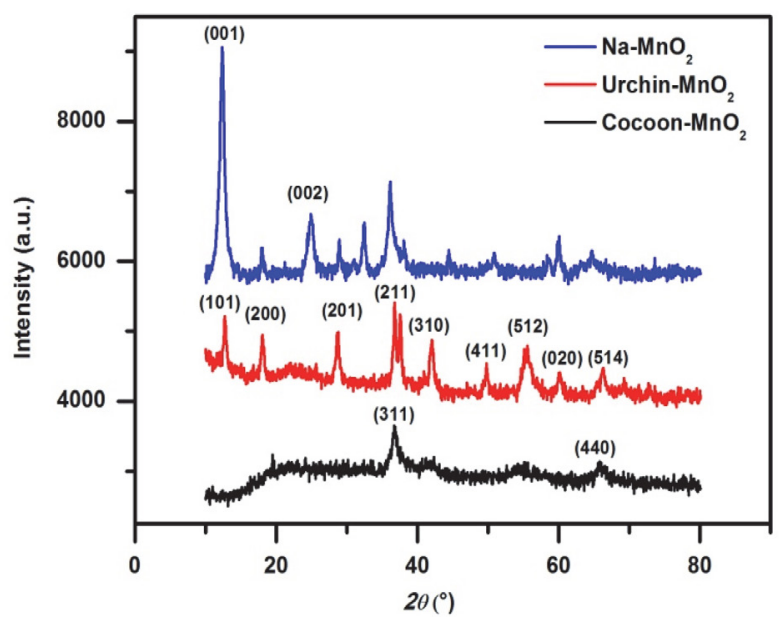

Figure 1. X-ray diffractograms of the synthesized manganese oxides materials. explained by the low crystallinity of the material. The poor crystallinity of the material was due to its synthesis at room temperature. The increase in the synthesis temperature made it possible to improve the material crystallinity but also to generate different morphologies. ${ }^{64,67}$ Nevertheless, the diffractogram revealed the presence of two diffraction peaks at $2 \theta=37^{\circ}$ (311) and $65^{\circ}$ (440), which had been indexed for the $\mathrm{MnO}_{2}$ type structure. It was deduced that the sample was in a weakly crystalline state with $\alpha-\mathrm{MnO}_{2}$ crystallographic forms. ${ }^{68}$ This material was characterized by a crystalline structure as $\mathrm{K}_{2} \mathrm{Mn}_{4} \mathrm{O}_{9}$ (Table 1).

For the Urchin- $\mathrm{MnO}_{2}$ material, the diffractogram showed several well-defined and symmetrical peaks indicating that the material was well crystallized. The peaks observed, at $2 \theta=12.8^{\circ}(101), 17.8^{\circ}(200), 28.6^{\circ}(201), 37.4^{\circ}$ (211), $41.6^{\circ}(310), 49.5^{\circ}(411), 59.9^{\circ}(512), 65^{\circ}(020)$ and $69.7^{\circ}$ (514), could easily be indexed with cryptomelane $\left(\mathrm{KMn}_{8} \mathrm{O}_{16}\right)$ with a space group (I2/m(12) (JCPDS sheet No 44-1386). ${ }^{64}$ This material had a tunnel structure whose cation $\mathrm{K}^{+}$was present in these cavities. ${ }^{69}$

The last diffractogram of $\mathrm{Na}-\mathrm{MnO}_{2}$ material, as shown in (Figure 1) had well-defined with symmetrical diffraction peaks (001) and (002) (JCPDS card \#01-0739669). ${ }^{70}$ They indicated that material was single-phase mineral and well crystallized. This phase corresponds to the family of birnessite type sodium manganese, which has a layered structure with crystal water and $\mathrm{Na}^{+}$between the $\mathrm{MnO}_{6}$ octahedral sheets. ${ }^{71}$ This oxide had a basal spacing of $0.714 \mathrm{~nm}$ along the c-axis with a single crystal water sheet between the $\mathrm{MnO}_{6}$ octahedral sheets. The diffraction peaks could be easily indexed as a monoclinic structure (space group: $\mathrm{C} 2 / \mathrm{m}){ }^{72}$ From the diffractograms, we noticed that the various synthesized oxides had slightly wide peaks. These materials had slightly different surface areas. The chemical formula, structures, the Mn (AOS) of each material were illustrated in Table 1 . The spacing between layers for $\mathrm{Na}-\mathrm{MnO}_{2}$ and the size of the tunnels for Urchin- $\mathrm{MnO}_{2}$ was calculated from the $2 \theta$ values of the peaks using a value of $1.541 \AA$ (copper anticathode wavelength).

Table 1. Crystalline parameters and composition of manganese oxide materials $\left(\mathrm{Na}-\mathrm{MnO}_{2}\right.$, Cocoon- $\mathrm{MnO}_{2}$, and Urchin- $\left.\mathrm{MnO}_{2}\right)$.

\begin{tabular}{|c|c|c|c|c|c|c|}
\hline Material & Chemical formula & d $(\AA)$ & $\operatorname{Mesh}$ parameters $(\AA)^{\star}$ & Structure $^{\star}$ & $\begin{array}{l}\text { Composition in } \\
\text { element }(\mathrm{ppm})^{\star *}\end{array}$ & $\begin{array}{l}(\mathrm{AOS}) \\
\text { of } \mathrm{Mn}\end{array}$ \\
\hline $\mathrm{Na}-\mathrm{MnO}_{2}$ & $\begin{array}{c}\mathrm{Na}_{0.55} \mathrm{Mn}_{2} \mathrm{O}_{4} \cdot\left(\mathrm{H}_{2} \mathrm{O}\right)_{1.5} \\
\text { (Birnessite) }\end{array}$ & 7.14 & $\begin{array}{l}\mathrm{a}=5.1750 \\
\mathrm{~b}=2.8490 \\
\mathrm{c}=7.3380\end{array}$ & Monoclinic & $\begin{array}{l}{[\mathrm{Mn}]=388.87} \\
{[\mathrm{Na}]=75}\end{array}$ & 3.580 \\
\hline Cocoon- $\mathrm{MnO}_{2}$ & $\mathrm{~K}_{2} \mathrm{Mn}_{4} \mathrm{O}_{9}$ & - & $\begin{array}{l}\mathrm{a}=\mathrm{b}=11.2950 \\
\mathrm{c}=21.870\end{array}$ & Hexagonal & $\begin{array}{l}{[\mathrm{Mn}]=704.16} \\
{[\mathrm{~K}]=34.79}\end{array}$ & 3.650 \\
\hline Urchin- $\mathrm{MnO}_{2}$ & $\begin{array}{c}\mathrm{KMn}_{8} \mathrm{O}_{16} \\
\text { (Cryptomelane) }\end{array}$ & 4.85 & $\begin{array}{l}a=b=9.840 \\
c=2.850\end{array}$ & Tetragonal & $\begin{array}{l}{[\mathrm{Mn}]=637.86} \\
{[\mathrm{~K}]=33.765}\end{array}$ & 3.730 \\
\hline
\end{tabular}

* determined by HighScore software. ${ }^{* *}$ determined by atomic absorption spectroscopy (AAS). 


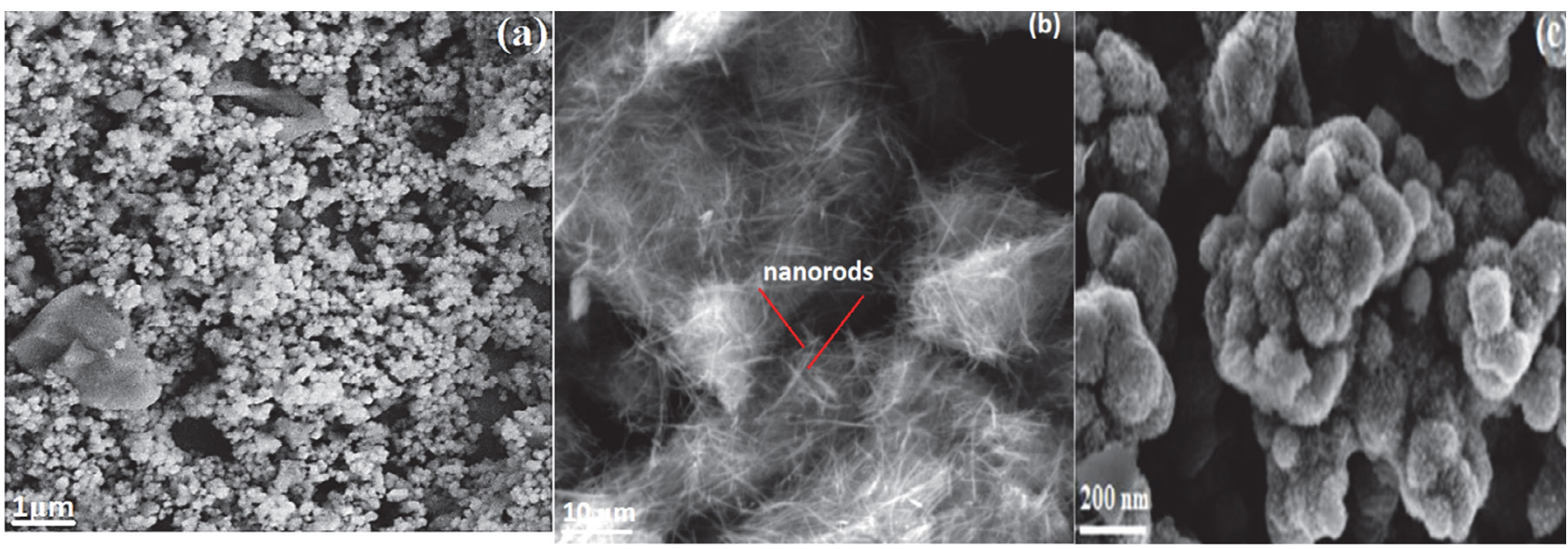

Figure 2. SEM images of (a) $\mathrm{Na}-\mathrm{MnO}_{2}$, (b) Urchin- $\mathrm{MnO}_{2}$, and (c) Cocoon- $\mathrm{MnO}_{2}$.

\section{2. SEM of $\mathrm{MnO}_{2}$ Lamellar and Nanostructures}

Scanning electron microscopy (SEM) was used to study the detailed surface morphology of the different synthesized materials. As seen in (Figure 2), the morphology of the materials was different.

The different SEM images showed that the surface morphology of these different materials was highly dependent on the preparation technique. Figure 2 showed that the $\mathrm{Na}-\mathrm{MnO}_{2}$ material (Figure 2 a) was composed of thin sheets which were agglomerated together to form particles several micrometers in size. The nanostructured material (Urchin- $\mathrm{MnO}_{2}$ ) obtained at $80^{\circ} \mathrm{C}$ (Figure $2 \mathrm{~b}$ ) had an urchin morphology and composed of a large number of nanorods with different sizes intertwining each other while the material obtained at room temperature (Figure $2 \mathrm{c}$ ) had a cocoon-shaped morphology composed of microspheres. ${ }^{64}$

\section{3. Isotherm BET}

All the characteristics of each material, including pore volume, pore size and specific surface area were determined using conventional nitrogen isothermal analysis. From Eq. (S1) we could determine the specific surface area of each material. The evolution of with of was linear (Figure 3).

Figure 3 showed the BET isothermal models for the three materials. The results of this study showed a high correlation between relative pressures $\frac{\mathrm{P}}{\mathrm{P}_{0}}$ and $\frac{1}{\mathrm{Q}\left[\left(\frac{\mathrm{P}_{0}}{\mathrm{P}}\right)-1\right]}$ that allowed us to determine the specific surface area of each material. According to Table 2, the three materials were characterized by a large specific surface area ranging from 30 to $44 \mathrm{~m}^{2} / \mathrm{g}$. These results showed that a large specific BET surface area provided an effective adsorbent. The BET surface of the $\mathrm{Na}-\mathrm{MnO}_{2}$ material was the lowest of the

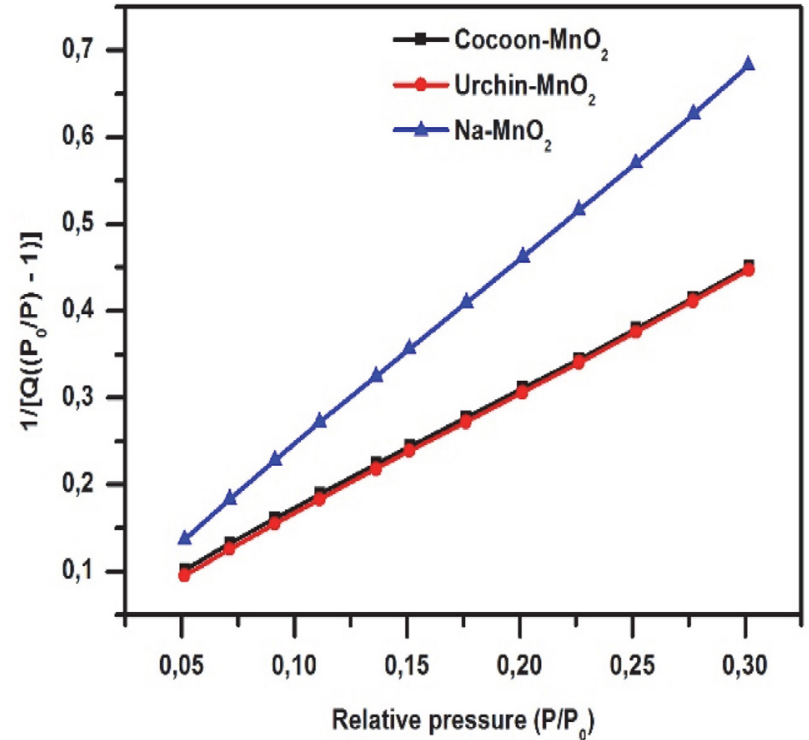

Figure 3. BET isotherm of materials $\mathrm{Na}-\mathrm{MnO}_{2}$, Cocoon- $\mathrm{MnO}_{2}$, and Urchin- $\mathrm{MnO}_{2}$.

Table 2. Isotherm parameters for BET models.

\begin{tabular}{lcccc}
\hline & Constant C & $\boldsymbol{S}_{\boldsymbol{B E T}}\left(\mathbf{m}^{2} / \mathbf{g}\right)$ & $\mathbf{Q}_{\mathbf{m}}$ & $\mathbf{R}^{\mathbf{2}}$ \\
\hline $\mathrm{Na} \mathbf{M n O}_{2}$ & 75.1 & $30.5 \pm 1.7$ & 0.457 & 0.9999 \\
Urchin-MnO $_{2}$ & 52.9 & $44.3 \pm 3.0$ & 0.705 & 0.9998 \\
${\text { Cocoon- } \mathbf{M n O}_{2}}^{2}$ & 41.1 & $43.9 \pm 3.3$ & 0.709 & 0.9998 \\
\hline
\end{tabular}

three materials, this weakness may be attributed to sodium insertion into the material.

Adsorption/desorption studies of $\mathrm{N}_{2}$ were performed to characterize the pore size distribution of the three materials, the resulting isotherms and Barrett-Joyner-Halenda $(\mathrm{BJH})$ pore size distribution diagrams were presented in Figure S1. According to the International Union of Pure and Applied Chemistry Classification (IUPAC), ${ }^{73}$ the curve corresponding to the $\mathrm{Na}-\mathrm{MnO}_{2}$ material had a type $\mathrm{V}$ shape with a type $\mathrm{H} 3$ hysteresis loop 
attributed to mesoporous solids. In contrast, the two materials Urchin- $\mathrm{MnO}_{2}$ and Cocoon- $\mathrm{MnO}_{2}$, their curves had a type II shape that corresponded to non-porous rather than macroporous solids.

The pore size classification suggested by the IUPAC ${ }^{74}$ was adopted. Analysis of the $\mathrm{BJH}$ pore distribution of the $\mathrm{Na}-\mathrm{MnO}_{2}$ material showed that mesopores ( $\mathrm{d}>50 \AA$ ) had about $52 \%$ of the total porous surface area. These results showed the predominance of mesopores in the $\mathrm{Na}-\mathrm{MnO}_{2}$ material. This parameter would be a factor and an essential element for the removal of metal ions. The two materials Urchin- $\mathrm{MnO}_{2}$ and Cocoon- $\mathrm{MnO}_{2}$, mesoporous, had $52 \%$ to $54 \%$ of the total area (Table S1). The average pore diameters for the two materials (Urchin- $\mathrm{MnO}_{2}$ and Cocoon- $\mathrm{MnO}_{2}$ ) were slightly small compared to $\mathrm{Na}-\mathrm{MnO}_{2}$ (Table S1). It was also noted from Figure S1 that the pore volume was distributed according to all pore sizes studied. All these parameters allowed having the materials with a high affinity of adsorption of heavy metals. During this study, we also surveyed the average diameters of the adsorption and desorption pores of the $\mathrm{BJH}$ model, as well as the cumulative volume of adsorption/desorption, the results obtained were illustrated in Table S1.

\section{4. $\mathrm{Pb}$ (II) and $\mathrm{Cd}$ (II) Removal by Manganese Oxides Materials}

\section{1. Effect of Contact Time on the Removal Efficiency of Heavy Metals}

The equilibrium study between the adsorbate (liquid phase) and the adsorbent (solid) was achieved with a speed that depended not only on the rate at which the components diffused into the adsorbent and in the fluid, but also on the adsorbent-adsorbate interaction. The time-dependent study of the adsorption of a compound on an adsorbent allowed us to examine the influence of contact time on its retention. The effect of contact time for the interaction studies between $\mathrm{Pb}(\mathrm{II}), \mathrm{Cd}(\mathrm{II})$, and the synthesized materials in an aqueous medium under ambient temperature conditions were given in Figure 4.

Figure 4 demonstrated that the prepared materials had a very high removal efficiency. The removal of lead ion could rapidly achieve the equilibrium within $15 \mathrm{~min}$ allowed to have a removal efficiency of $97.44,93.15$, and 98.77\% for $\mathrm{Na}-\mathrm{MnO}_{2}$, Urchin- $\mathrm{MnO}_{2}$, and Cocoon- $\mathrm{MnO}_{2}$, respectively. In the case of $\mathrm{Cd}(\mathrm{II})$ ions, the materials also showed high reactivity to this metal cation during contact. The highest yield was up to $99 \%$ for $\mathrm{Na}-\mathrm{MnO}_{2}$ material during 30 minutes of interaction, while in the case of Urchin- $\mathrm{MnO}_{2}$ and Cocoon- $\mathrm{MnO}_{2}$, the yields were $55.33 \%$ and $80.26 \%$ respectively.

Several parameters could be discussed to explain the behavior of $\mathrm{Pb}(\mathrm{II})$ and $\mathrm{Cd}(\mathrm{II})$ ions during interaction with synthesized materials such as the specific surface area, the acid-base properties of the materials, and certainly their composition and $\mathrm{Mn}$ (AOS). In this work, we determined the Mn (AOS) for each material using a specific dosage. The results showed that the materials had an oxidation degree average about 3.5. Therefore, the manganese oxide material was a mixture of $\mathrm{Mn}(\mathrm{III})$ and $\mathrm{Mn}(\mathrm{IV})$ with $\mathrm{Mn}(\mathrm{IV})$ dominated (Table 1). Studies had been done to examine the effect of oxidation degree on the removal efficiency of heavy metals. ${ }^{49}$ The results showed that adsorption capacity increased with increasing oxidation degree. This significant correlation may indicate that samples with a high degree of oxidation contained more octahedral cationic vacancy sites, which were primarily responsible for heavy metals sorption. According to the BET isotherm
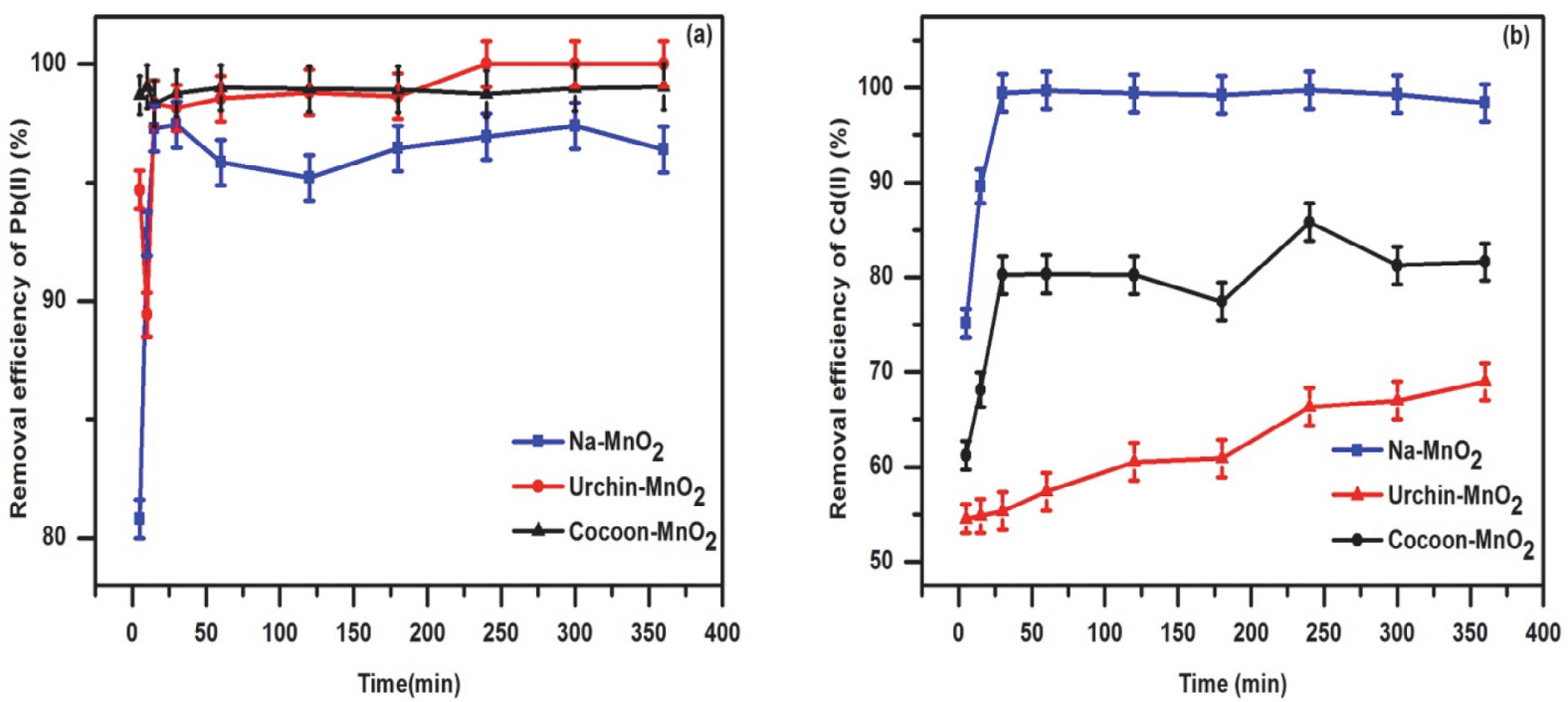

Figure 4. Effect of contact time on (a) $\mathrm{Pb}(\mathrm{II})$ and (b) $\mathrm{Cd}(\mathrm{II})$ removal by $\mathrm{Na}-\mathrm{MnO}_{2}$, Urchin $-\mathrm{MnO}_{2}$ and Cocoon- $\mathrm{MnO}{ }_{2}\left([\mathrm{~Pb}(\mathrm{II})]_{\text {initial }}=[\mathrm{Cd}(\mathrm{II})]_{\text {initial }}\right.$ $=30 \mathrm{ppm}$ ). 
performed for the three synthesized materials, we had found that these oxides had high specific surfaces (Table 2). This parameter was an essential factor in the properties of an adsorbent. The pore diameter could make possible to enhance metal ions elimination. Also, as noticed previously that the $\mathrm{Na}-\mathrm{MnO}_{2}$ material was characterized by the largest pore diameter $(\mathrm{d}=66.63 \AA)$ compared to the two types of manganese oxides (Table S1). Higher yields recorded for the two metal ions were also enhanced at high $\mathrm{pH}$, which was attributed to the formation of $\mathrm{MOH}^{+}(\mathrm{M}=$ metal cation) species with the increase in $\mathrm{pH}$. Therefore, the formation of $\mathrm{MOH}^{+}$species conducted to higher adsorption. S. Wan et al. have shown that manganese oxides can trapped metal ions, specifically $\mathrm{Pb}$ (II) and $\mathrm{Cd}(\mathrm{II})$ ions, by electrostatic forces and formation of inner-sphere complexes, ${ }^{75}$ rendered it an efficient material for the removal of metal ions in the aqueous medium.

The comparative study on the performance obtained during the interaction of oxides with $\mathrm{Pb}$ (II) and $\mathrm{Cd}(\mathrm{II})$ (Figure S2) showed that the $\mathrm{Na}-\mathrm{MnO}_{2}$ material had a significant affinity for ( $\mathrm{Cd}(\mathrm{II})$ and $\mathrm{Pb}(\mathrm{II})$ ) removal in an aqueous medium. On the other hand, the Urchin- $\mathrm{MnO}_{2}$ and Cocoon- $\mathrm{MnO}_{2}$ materials had more affinity for $\mathrm{Pb}(\mathrm{II})$ than $\mathrm{Cd}(\mathrm{II})$. Several parameters can explain the difference between the yields recorded for $\mathrm{Cd}(\mathrm{II})$ and $\mathrm{Pb}$ (II). When the lamellar materials $\left(\mathrm{Na}-\mathrm{MnO}_{2}\right)$ interacted with the $\mathrm{Pb}$ (II) and $\mathrm{Cd}(\mathrm{II})$ ions, the $\mathrm{Pb}(\mathrm{II})$ ions occupied the interlayer $\mathrm{MnO}_{6}$ and surface sites, ${ }^{76}$ while the $\mathrm{Cd}(\mathrm{II})$ mainly occupied the sites above and below the octahedrons of $\mathrm{MnO}_{6}{ }^{65,77}$ The removal efficiency for each metal ion depended strongly on its hydrolysis constant. Indeed, this elimination capacity increased with the hydrolysis constants $^{78}$ of $\mathrm{Pb}$ (II) and $\mathrm{Cd}(\mathrm{II})$, which were respectively $10^{-}$ 7.7 and $10^{-10.1}$. The cationic exchange was better at low $\mathrm{pK}$ value. ${ }^{79}$ The $\mathrm{pH}$ of the medium studied $(\mathrm{pH}=6.5)$ was less than the $\mathrm{pK}$ of $\mathrm{Pb}(\mathrm{II})$ and $\mathrm{Cd}(\mathrm{II})$ (7.7 and 10.1), indicating that the hydroxylation cations were formed by hydrolysis induced by the surfaces of the manganese oxide. ${ }^{80}$ The metal valency, as well as it's a hydrated radius $\left(\mathrm{r}_{\text {hydrated }}=\mathrm{r}\right.$ ion $+2 \mathrm{r}_{\mathrm{H} 2 \mathrm{O}}$ with $\mathrm{r}_{\mathrm{H} 2 \mathrm{O}}=0.138 \mathrm{~nm}$ ) was also an important parameter in adsorption phenomenon. ${ }^{59}$ Indeed, the higher the valency of the cation, the higher the affinity of the material towards this cation. For equal valence, the cations with a high volume that will be fixed first ( $\mathrm{Pb}$ (II) $(1.19 \AA)$ $>\mathrm{Cd}(\mathrm{II})(0.95 \AA)$.

\section{2. Effect of $\mathrm{pH}$ on the Removal Efficiency of Heavy Metals}

To investigate the effect of $\mathrm{pH}$ on the removal efficiency of metal ions by different materials, the adsorption of $\mathrm{Pb}$ (II) or $\mathrm{Cd}(\mathrm{II})$ ions was studied in the $\mathrm{pH}$ range of 2.0 to 9.0. The evolution of removal efficiencies of $\mathrm{Pb}$ (II) and $\mathrm{Cd}(\mathrm{II})$ $\mathrm{pH}$ solution after 30 min interaction were shown in Figure 5.

For the different materials, the removal percentages of the two metal ions were favored by the increase in $\mathrm{pH}$ from 2.0 to 9.0. This behavior may be explained by the increase in the number of negatively charged sites on the surface of the materials, which promoted the diffusion process of the metal ions and thus facilitated their removal by the different types of manganese oxide material. At lower $\mathrm{pH}$ values $(\mathrm{pH}=2)$, the lamellar material maintained its adsorptive power with yields of $83 \%$ and $71 \%$ in the case of $\mathrm{Pb}$ (II) and $\mathrm{Cd}(\mathrm{II})$ respectively. The slight decrease in removal efficiencies of $\mathrm{Pb}(\mathrm{II})$ and $\mathrm{Cd}(\mathrm{II})$ ions by the different materials may be due to the effect of competition between $\mathrm{H}^{+}$ions and metal ions. ${ }^{81}$ The highest removal $>94 \%$ in the case of $\mathrm{Pb}(\mathrm{II})$ was recorded at $\mathrm{pH}=6.5$. In the case of $\mathrm{Cd}(\mathrm{II})$ and above this $\mathrm{pH}$, the highest efficiencies were achieved with the lamellar material $\mathrm{Na}-\mathrm{MnO}_{2}$ with a value
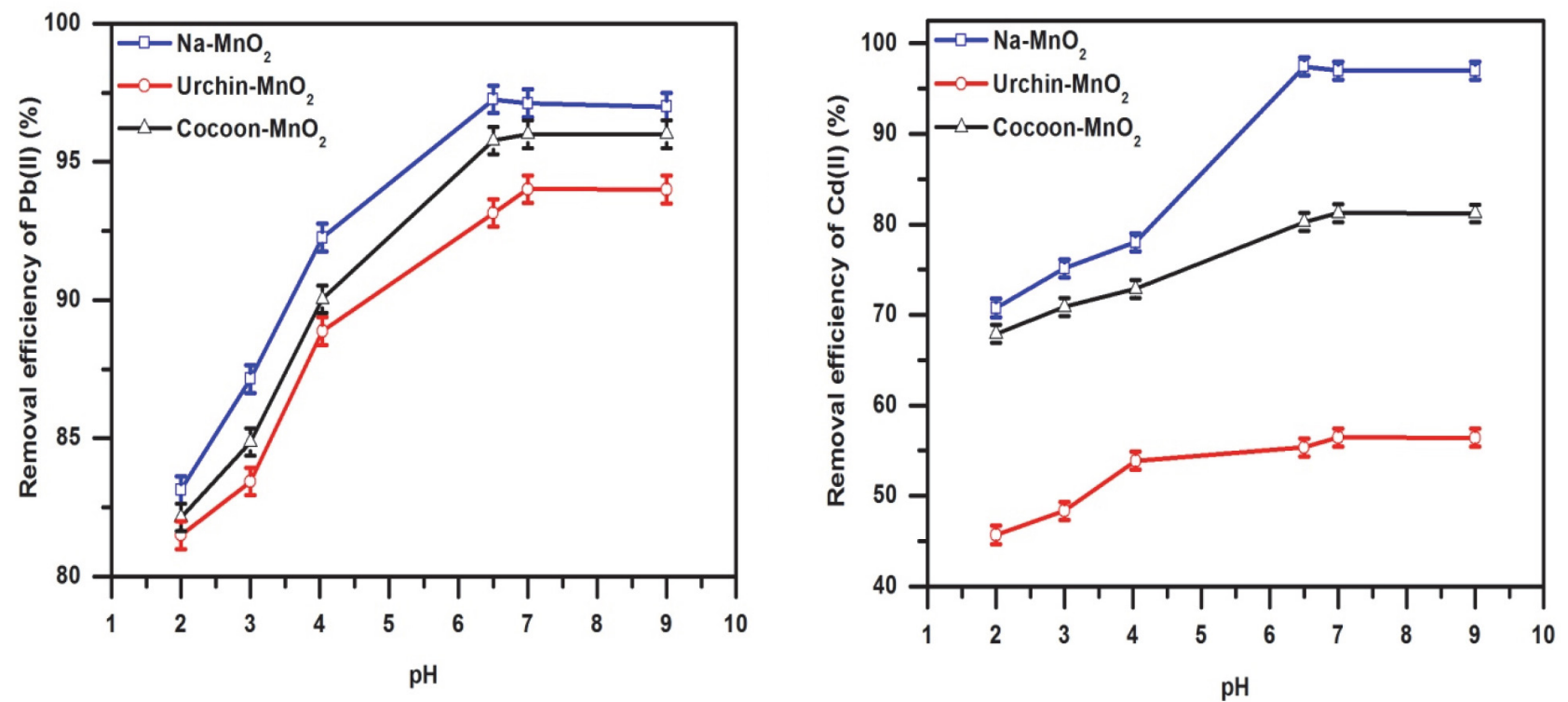

Figure 5. Effect of $\mathrm{pH}$ on the removal efficiency of metal ions by manganese oxide materials. 
of $97 \%$. In comparison, the two nanostructured materials recorded efficiencies of $56 \%$ and $81 \%$ for Urchin- $\mathrm{MnO}_{2}$ and Cocoon- $\mathrm{MnO}_{2}$, respectively. At values of $\mathrm{pH} \geq 6.5$, the removal efficiencies of metal ions were increased and remained almost stable up to $\mathrm{pH}=9$, which reflected the effect that under alkaline conditions, the concentration of $\mathrm{H}^{+}$protons was changed and the material, therefore, maintained its performance and removal capacity. In addition to these $\mathrm{pH}$ values, the two phenomena of adsorption and precipitation could be the predominant mechanisms for removing the two metal ions. ${ }^{81}$ In effect, the further treatment during this study was carried out at a free $\mathrm{pH}$ (6.5).

\section{3. Study of Manganese Oxides Stability During Interaction with Metal Cations}

During metal ion removal processes, manganese oxides could release manganese ions. To evaluate the manganese oxides stability, it was necessary to determine the $\mathrm{Mn}$ released by the different materials at different $\mathrm{pH}$ solutions. Figure 6 showed the percentages of manganese released in the case of interaction between the different materials and two metal ions $\mathrm{Pb}$ (II) and $\mathrm{Cd}(\mathrm{II})$.

From Figure 6, we noticed that during the removal of the two metal ions, the percentages of $\mathrm{Mn}$ released decreased with the $\mathrm{pH}$ increased from 2.0 to 9.0. At acidic $\mathrm{pH}$ values (2.0-4.0), the materials released more manganese. This release was probably due to the dissolution of manganese ions during the removal of metal ions. In $\mathrm{pH} \geq 6.5$, the manganese released by materials during interaction with $\mathrm{Pb}(\mathrm{II})$ and $\mathrm{Cd}(\mathrm{II})$ was low or even negligible. These results showed very high stability of the materials in neutral and alkaline $\mathrm{pH}$. The greatest stability was recorded for the $\mathrm{Na}$ $\mathrm{MnO}_{2}$ lamellar material. For example, at $\mathrm{pH}=6.5$, in the case of $\mathrm{Na}-\mathrm{MnO}_{2}$ lamellar material, the percentages of manganese released were very weak $(0.013 \%(0.123 \mathrm{mmol} /$ $\mathrm{Kg}$ ) and $0.31 \%(2.822 \mathrm{mmol} / \mathrm{Kg})$ during $\mathrm{Pb}(\mathrm{II})$ and $\mathrm{Cd}(\mathrm{II})$ adsorption respectively). The Urchin- $\mathrm{MnO}_{2}$ material released a very small amount of $0.93 \%(4.034 \mathrm{mmol} / \mathrm{Kg})$ of the total manganese during $\mathrm{Pb}$ (II) removal, whereas in the case of cadmium, a release rate of $6.08 \%(26.422 \mathrm{mmol} / \mathrm{Kg})$ was recorded. The highest amount of released manganese was obtained in the case of the Cocoon- $\mathrm{MnO}_{2}$ material $(6.3 \%(66.787 \mathrm{mmol} / \mathrm{Kg})$ during the removal of $\mathrm{Pb}(\mathrm{II})$ and $7.09 \%(75.22 \mathrm{mmol} / \mathrm{Kg})$ during the removal of Cd(II)). The results obtained showed that for the two nanostructures Urchin- $\mathrm{MnO}_{2}$ and Cocoon- $\mathrm{MnO}_{2}$ that the maximum amount of total manganese released decreased with increasing $\mathrm{Mn} \mathrm{AOS}^{47}$ (Mn AOS: Urchin- $\mathrm{MnO}_{2}$ (3.730)>Cocoon- $\mathrm{MnO}_{2}$ (3.650).

This study indicated that manganese oxide materials presented high stability. The high stability of these materials was strongly due to the stabilizing power and binding strength of the $\mathrm{Na}^{+}$and $\mathrm{K}^{+}$cations present in the structure of the three materials. ${ }^{82}$ The best stability among the different structures was recorded in the case of the lamellar structure $\left(\mathrm{Na}-\mathrm{MnO}_{2}\right)$, which presented a very low amount of the manganese release. This result confirmed that the use of Na$\mathrm{MnO}_{2}$ material with a lamellar structure compared to nanostructures responded to several requirements such as fast elimination kinetics and high reactivity to both heavy metals and also the factors of stability. This parameter is an essential factor in the use of materials in the form of the adsorbent. Na- $\mathrm{MnO}_{2}$ material can be used in more advanced applications and more precisely in the industrial sector for the treatment of contaminated waste by heavy metals.

\section{4. Adsorption Kinetics}

The sorption kinetics of $\mathrm{Pb}(\mathrm{II})$ and $\mathrm{Cd}(\mathrm{II})$ on manganese oxide materials was evaluated, and the results were shown in Figure 7. The adsorption equilibrium was achieved within $30 \mathrm{~min}$. The kinetics data were fitted according to pseudo-first order (Eq. (4)) and pseudo-second
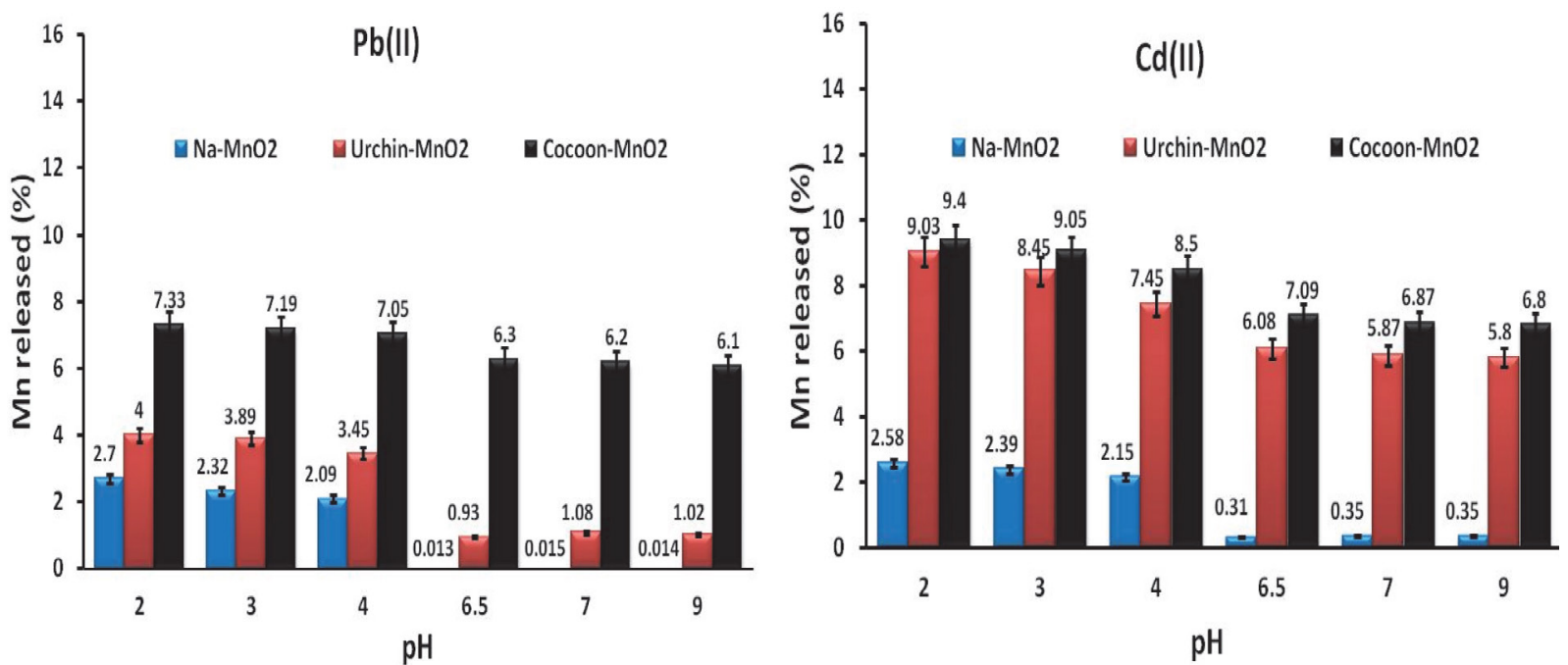

Figure 6. Percentages of manganese released by manganese oxides during interaction with $\mathrm{Pb}(\mathrm{II})$ and $\mathrm{Cd}(\mathrm{II})$ at different $\mathrm{pH}$ solution. 
order (Eq. (5)) equations. The adsorbed quantities $\mathrm{q}_{\mathrm{exp}}$, the order of the constants $K$ and regression coefficients $R^{2}$ were shown in Table S2.

$$
\begin{aligned}
& \ln \left(\mathrm{q}_{\mathrm{e}}-\mathrm{q}_{\mathrm{t}}\right)=-\mathrm{Kt}+\ln \left(\mathrm{q}_{\mathrm{e}}\right) \\
& \frac{\mathrm{t}}{\mathrm{q}_{\mathrm{t}}}=\frac{1}{\left(\mathrm{kx} \mathrm{q}_{\mathrm{e}}^{2}\right)}+\left(\frac{1}{\mathrm{q}_{\mathrm{e}}}\right) \mathrm{t}
\end{aligned}
$$

With:

$q_{e}(\mathrm{mg} / \mathrm{g})$ and $q_{t}(\mathrm{mg} / \mathrm{g})$ were the adsorbed quantities of $\mathrm{Pb}(\mathrm{II})$ or Cd(II) at equilibrium and time $t$ ( $\mathrm{min}$ ).

$K$ : rate constant of the pseudo-first order model $\left(\mathrm{min}^{-1}\right)$.

$k$ : rate constant of the pseudo-second order model $\left(m g \cdot g^{-1} \cdot m^{-1}\right)$.

Figure 7 and Table S2 showed that the second-order $R^{2}$ values are very high and were all higher than those ob-

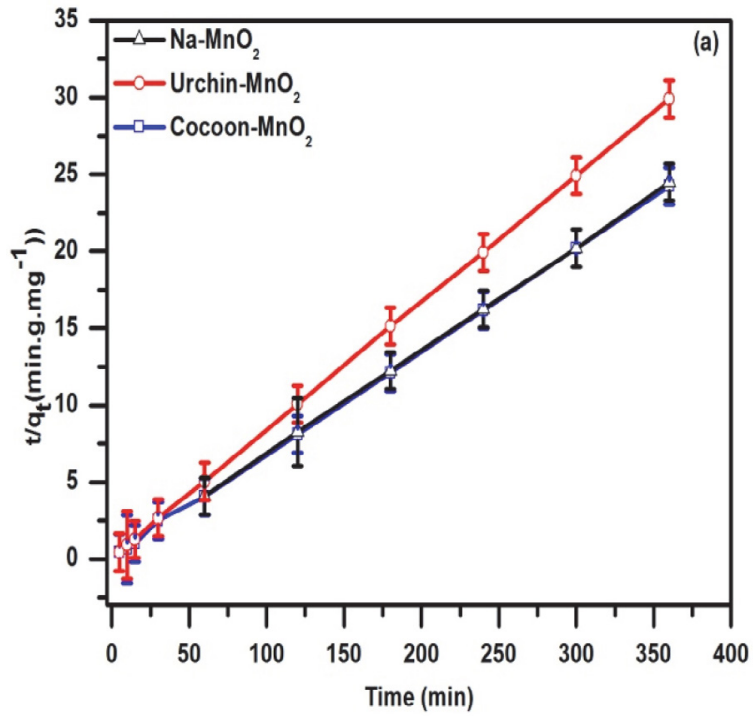

tained with the pseudo-first order model. The quantities fixed at equilibrium $\mathrm{q}_{\mathrm{e}}$ were closed to the values obtained experimentally for the two metals. The adsorption process of $\mathrm{Pb}(\mathrm{II})$ and $\mathrm{Cd}(\mathrm{II})$ followed the pseudo-second order model. This model suggested the existence of chemisorption with the formation of a monomolecular layer. ${ }^{83}$ In fact, the pseudo-second order constant (K) gave an idea of the affinity of the material towards metal ions. ${ }^{77}$ Based on the results shown in Table S2, we could deduce that the three materials used have a higher affinity for $\mathrm{Pb}$ (II) than for $\mathrm{Cd}(\mathrm{II})$.

\section{5. Influence of the Initial Concentration of Metal Ions on the Removal Efficiency of Manganese Oxides}

The influence of the initial concentration of metal ions on manganese oxide removal efficiencies was carried

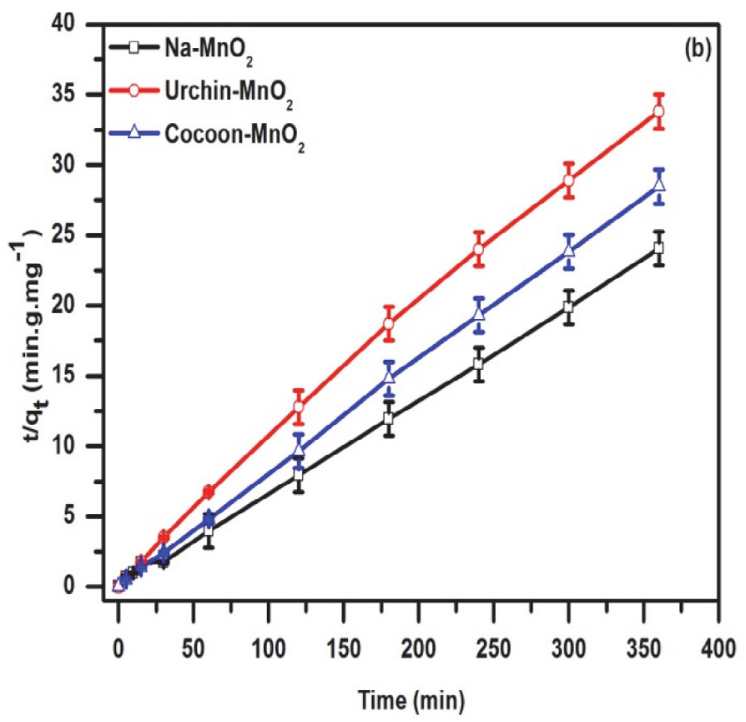

Figure 7. Adsorption kinetic diagram of (a) $\mathrm{Pb}(\mathrm{II})$ and (b) $\mathrm{Cd}(\mathrm{II})$ on $\mathrm{Na}-\mathrm{MnO}_{2}$, Urchin- $\mathrm{MnO}_{2}$ and Cocoon- $\mathrm{MnO}_{2}$.
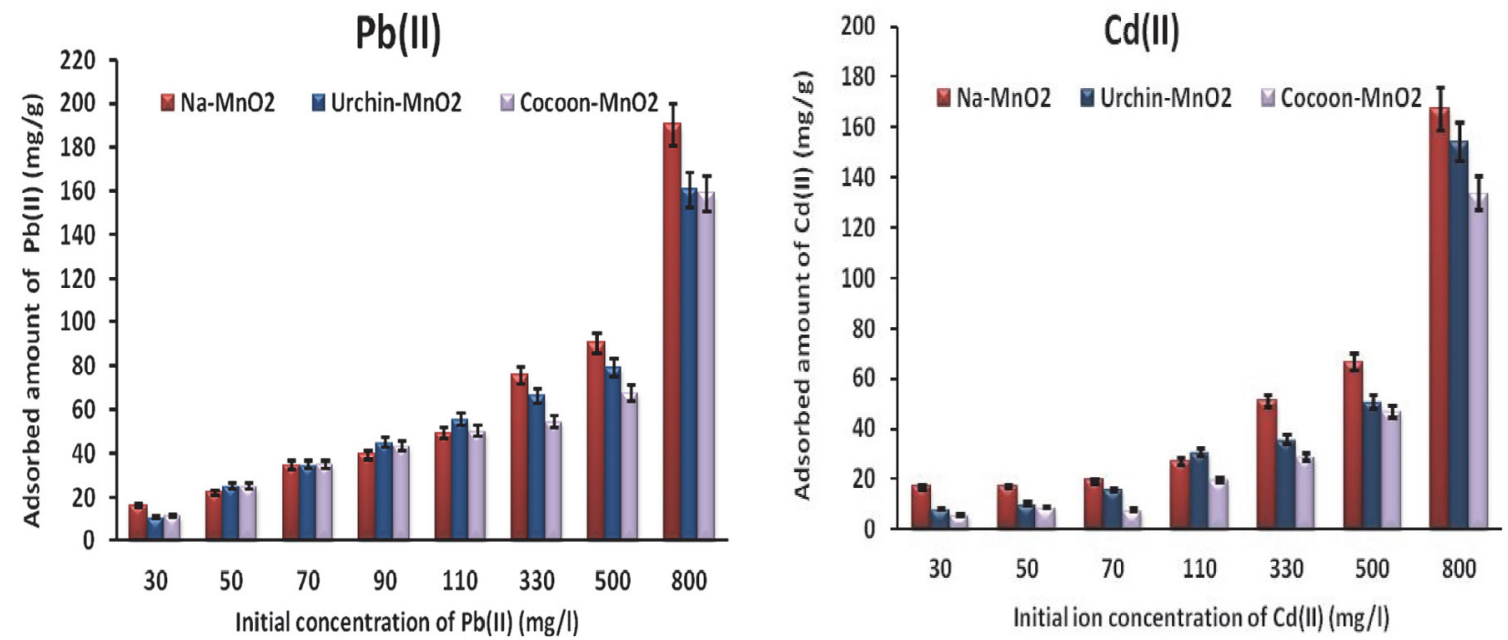

Figure 8. Influence of the initial concentration of metal ions on the removal efficiencies of $\mathrm{Pb}(\mathrm{II})$ and $\mathrm{Cd}(\mathrm{II})$ by manganese oxides. 
out with different metal ion concentrations ranging from 30 to $800 \mathrm{ppm}$ for 30 minutes of interaction. The results obtained were shown in Figure 8.

The examination of Figure 8 showed an increase in the removal efficiency of metal cations with increasing concentration. High removal capacities were recorded for $\mathrm{Pb}$ (II) for all three materials due to their high affinity toward this metal. For an initial concentration of $800 \mathrm{ppm}$ of $\mathrm{Pb}$ (II), Urchin- $\mathrm{MnO}_{2}$ and Cocoon- $\mathrm{MnO}_{2}$ materials were able to absorb $160 \mathrm{mg} / \mathrm{g}$, while $\mathrm{Na}-\mathrm{MnO}_{2}$ adsorbed a larger amount of $190 \mathrm{mg} / \mathrm{g}$. For the same initial concentration of $\mathrm{Cd}(\mathrm{II})$, the three materials removed an quantity ranging from 140 to $160 \mathrm{mg} / \mathrm{g}$ with the highest amount recorded for $\mathrm{Na}-\mathrm{MnO}_{2}$.

\section{6. Isotherm Models}

In this study, the adsorption equilibrium was modeled using three mathematical laws Langmuir, Freundlich, and Temkin, which represented the equilibrium relationship between the amount of metal cation in the liquid phase $\left(\mathrm{C}_{\mathrm{e}}\right)$ and that adsorbed on the material $\left(\mathrm{q}_{\mathrm{e}}\right)$.

Adsorption studies were conducted for 30 minutes at different initial concentrations of $\mathrm{Pb}$ (II) and $\mathrm{Cd}(\mathrm{II})$ metal ions and $100 \mathrm{mg}$ of the material. The isotherms were given in Figure S3. The following equations represented the models of each isotherm applied in this study:

$$
\text { Langmuir isotherm: } \frac{\mathrm{C}_{\mathrm{e}}}{\mathrm{q}_{\mathrm{e}}}=\left(\frac{1}{\mathrm{bx} \mathrm{q_{m }}}\right)+\mathrm{C}_{\mathrm{e}}\left(\frac{1}{\mathrm{q}_{\mathrm{m}}}\right)
$$

Freundlich isotherm: $\log \mathrm{q}_{\mathrm{e}}=\log \mathrm{K}_{\mathrm{F}}+\frac{1}{\mathrm{n}}\left(\log \mathrm{C}_{\mathrm{e}}\right)$
Temkin isotherm: $\mathrm{q}_{\mathrm{e}}=\left(\frac{\mathrm{RT}}{\mathrm{b}_{\mathrm{T}}}\right) \ln \mathrm{K}_{\mathrm{T}}+\left(\frac{\mathrm{RT}}{\mathrm{b}_{\mathrm{T}}}\right) \ln \mathrm{C}_{\mathrm{e}}$

For the Langmuir isotherm, another parameter could also be expressed as a constant representing the separation factor defined by Eq. (9).

$$
\mathrm{R}_{\mathrm{L}}=\frac{1}{1+\mathrm{b} \times \mathrm{C}_{0}}
$$

A separation factor $R_{L}>1$ indicated that the adsorption was unfavorable, if $\mathrm{R}_{\mathrm{L}}=1$ the adsorption was described as linear, the adsorption was considered to be favorable when $0<\mathrm{R}_{\mathrm{L}}<1$ and a zero separation factor $\left(\mathrm{R}_{\mathrm{L}}=0\right)$ indicated that the adsorption was irreversible. ${ }^{84}$

With:

$C_{e}$ : the equilibrium concentration of substrates in the solution $(m g / L)$.

$q_{e}$ : the adsorption capacity at equilibrium $(\mathrm{mg} / \mathrm{g})$.

$q_{m}$ : the maximum amount of adsorption $(\mathrm{mg} / \mathrm{g})$.

$b$ : the adsorption equilibrium constant $(\mathrm{L} / \mathrm{mg})$.

$K_{F}$ : a constant representing the adsorption capacity.

$n$ : the constant showing the adsorption intensity.

$R=8.314 \mathrm{~J} \mathrm{~mol}^{-1} \mathrm{~K}^{-1}$.

T: absolute temperature in $(K), K_{T}$ : Temkin constant in $\left(L m g^{-1}\right)$.

$C_{0}$ : the initial concentration of the adsorbate $\left(\mathrm{mg} \mathrm{L}^{-1}\right)$.

Figure $\mathrm{S} 3$ showed the most appropriate isotherms for the three materials $\mathrm{Na}-\mathrm{MnO}_{2}$, Urchin- $\mathrm{MnO}_{2}$, and Cocoon- $\mathrm{MnO}_{2}$. In table $\mathrm{S} 3$ all parameters of the isotherms for the two metals were given. After studying the isothermal adsorption of $\mathrm{Pb}(\mathrm{II})$ and $\mathrm{Cd}(\mathrm{II})$ ions by manganese oxides,

Table 3. Comparison of $\mathrm{Pb}(\mathrm{II})$ and $\mathrm{Cd}(\mathrm{II})$ adsorption capacities of $\mathrm{Na}-\mathrm{MnO}_{2}$, Urchin- $\mathrm{MnO}_{2}, \mathrm{Cocoon}-\mathrm{MnO}_{2}$

\begin{tabular}{|c|c|c|c|}
\hline Sorbent & $\begin{array}{c}\text { Adsorption } \\
\text { capacity }(\mathbf{m g} / \mathrm{g})\end{array}$ & Conditions & References \\
\hline \multicolumn{4}{|c|}{$\mathrm{Pb}(\mathrm{II})$} \\
\hline K-Birnessite & 164.30 & $\mathrm{pH}=5, \mathrm{~T}^{\circ}=25^{\circ} \mathrm{C}$ & 85 \\
\hline $\mathrm{Al}_{2} \mathrm{O}_{3}$-supported iron oxide & 28.98 & $\mathrm{pH}=5, \mathrm{~T}^{\circ}=27^{\circ} \mathrm{C}$ & 86 \\
\hline $\mathrm{Fe}_{3} \mathrm{O}_{4}$ nanoparticles & 83 & & 87 \\
\hline $\mathrm{TiO}_{2}$ nanoparticles & 159 & $\mathrm{pH}=7, \mathrm{~T}^{\circ}=25^{\circ} \mathrm{C}$ & \\
\hline Cocoon- $\mathrm{MnO}_{2}$ & 209 & & \\
\hline Urchin- $\mathrm{MnO}_{2}$ & 264 & $\mathrm{pH}=6.5, \mathrm{~T}^{\circ}=25^{\circ} \mathrm{C}$ & This study \\
\hline $\mathrm{Na}-\mathrm{MnO}_{2}$ & 297 & & \\
\hline \multicolumn{4}{|c|}{$\mathrm{Cd}(\mathrm{II})$} \\
\hline Birnessite & 34 & $\mathrm{pH}=7, \mathrm{~T}^{\circ}=25^{\circ} \mathrm{C}$ & 88 \\
\hline Synthetic zeolites & 50.8 & $\mathrm{pH}=6, \mathrm{~T}^{\circ}=25^{\circ} \mathrm{C}$ & 89 \\
\hline Activated carbon cloth & 146 & $\mathrm{pH}=6, \mathrm{~T}^{\circ}=25^{\circ} \mathrm{C}$ & 90 \\
\hline Cocoon- $\mathrm{MnO}_{2}$ & 172 & & \\
\hline Urchin- $\mathrm{MnO}_{2}$ & 191 & $\mathrm{pH}=6.5, \mathrm{~T}^{\circ}=25^{\circ} \mathrm{C}$ & This study \\
\hline $\mathrm{Na}-\mathrm{MnO}_{2}$ & 199 & & \\
\hline
\end{tabular}
and other reported adsorbents. 
it could be seen that the best description of the adsorption phenomenon was obtained with the Langmuir model with a high correlation coefficient $\mathrm{R}^{2}$ (Table S3). This applied model allowed us to determine the maximum adsorption quantity $\mathrm{q}_{\mathrm{m}}(\mathrm{mg} / \mathrm{g})$ for all materials interacting with the two metal cations (Table S3). For $\mathrm{Pb}(\mathrm{II})$, the maximum quantities adsorbed were $297 \mathrm{mg} / \mathrm{g}\left(\mathrm{Na}-\mathrm{MnO}_{2}\right), 264 \mathrm{mg} / \mathrm{g}$ (Urchin- $\mathrm{MnO}_{2}$ ), and $209 \mathrm{mg} / \mathrm{g}$ for the material Cocoon- $\mathrm{MnO}_{2}$. For $\mathrm{Cd}(\mathrm{II})$, the adsorbed quantities were 199 $\mathrm{mg} / \mathrm{g}\left(\mathrm{Na}-\mathrm{MnO}_{2}\right), 191 \mathrm{mg} / \mathrm{g}\left(\right.$ Urchin- $\left.\mathrm{MnO}_{2}\right)$, and 172 $\mathrm{mg} / \mathrm{g}\left(\right.$ Cocoon- $\mathrm{MnO}_{2}$ ). In addition, the developed lamellar materials and nanostructures had shown a high adsorption capacity compared to other types of adsorbents (Table 3).

The description of the adsorption of $\mathrm{Pb}(\mathrm{II})$ and Cd(II) by the Langmuir model that the adsorption of these ions by the materials was done by the formation of a monolayer on the external surface of the adsorbent. Thus, this concordance could be explained by the homogeneity of the adsorption sites on the surface of these materials. Indeed, during the interaction, there would be a direct contact of metal ions on the surface of the materials up to the coverage of the monolayer. Based on the calculated $\mathrm{R}_{\mathrm{L}}$ values, all values were between 0 and 1 , indicating favorable adsorption.

In the structure of synthesized manganese oxides of the birnessite type $\left(\mathrm{A}_{\mathrm{x}} \mathrm{MnO}_{2}, \mathrm{zH}_{2} \mathrm{O}\right)$ (with $\mathrm{A}=\mathrm{Na}^{+}$ (case: $\left.\mathrm{Na}-\mathrm{MnO}_{2}\right)$ ), either $\mathrm{Na}^{+}$and $\mathrm{H}^{+}{ }^{91}$ or $\mathrm{Mn}^{2+}$, two proton or $(\mathrm{Mn}(\mathrm{III}) \mathrm{OH})^{2+}$ were located on each side of a vacant cationic site to obtain local charge balance of material. ${ }^{47}$ The analysis of sodium $\left(\mathrm{Na}^{+}\right)$in solution during the removal of $\mathrm{Cd}(\mathrm{II})$ and $\mathrm{Pb}$ (II) confirmed this hypothesis. The result indicated that $\mathrm{Na}-\mathrm{MnO}_{2}$ material released a quantity of $\mathrm{Na}^{+}$ions during removal processes (Figure S4).

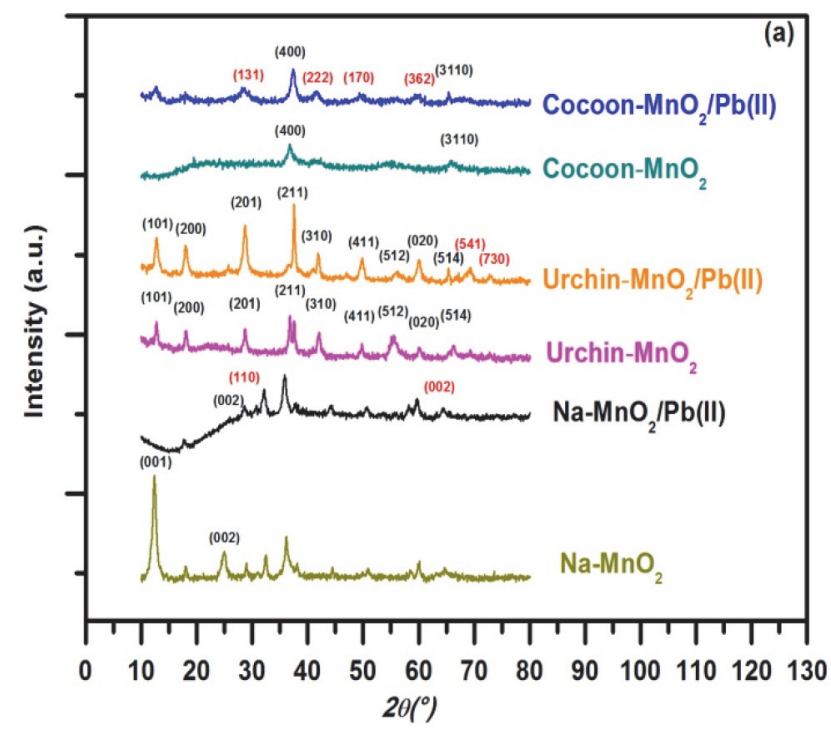

As shown in $\mathrm{X}$-ray diffractogram, the two materials Urchin- $\mathrm{MnO}_{2}\left(\mathrm{KMn}_{8} \mathrm{O}_{16}\right)$ and Cocoon- $\mathrm{MnO}_{2}\left(\mathrm{~K}_{2} \mathrm{Mn}_{4} \mathrm{O}_{9}\right)$ had two different structures, with $\mathrm{K}^{+}$ions inserted into their cavities. The removal of $\mathrm{Cd}(\mathrm{II})$ and $\mathrm{Pb}$ (II) occurred by exchanging $\mathrm{K}^{+}$from the tunnel site and also on the external surface of the materials. ${ }^{92}$ The exchange between the metal ions and the $\mathrm{K}^{+}$caused it to be released into the solution during the metal removal process (Figure S5).

\section{Analysis of the Adsorption Mechanism}

\section{1. X-ray Diffraction}

The characterization by X-ray diffraction of the materials after interaction with metallic cations was important to determine the totality of structures formed. The diffractograms before and after interaction with $\mathrm{Pb}(\mathrm{II})$ and Cd(II) were illustrated in Figure 9.

After the interaction of the manganese oxide materials with $\mathrm{Pb}$ (II) and $\mathrm{Cd}(\mathrm{II})$, the diffractograms of each material were not similar. The peaks obtained from each material were analyzed to determine the phases formed. The crystallographic parameters of each phase were represented in Table 4.

In the case of $\mathrm{Na}-\mathrm{MnO}_{2}$, after interaction with $\mathrm{Pb}(\mathrm{II})$ and $\mathrm{Cd}(\mathrm{II})$, a slight decrease in the intensity of some peaks occurred. The identification of the phases formed made it possible to determine the $\mathrm{MnO}_{2}$ manganese oxide phase and the appearance of new $\mathrm{PbO}$ phases observed at $2 \theta=30.66^{\circ}(110), 64.40^{\circ}(002)$ and for the $\mathrm{Cd}(\mathrm{OH})_{2}$ phase was indexed in two peaks located at $2 \theta=$ $50^{\circ}$ (231), $53.64^{\circ}(002)$ indicating that the $\mathrm{Pb}(\mathrm{II})$ and $\mathrm{Cd}(\mathrm{II})$ ions had been inserted into the material. The iden-

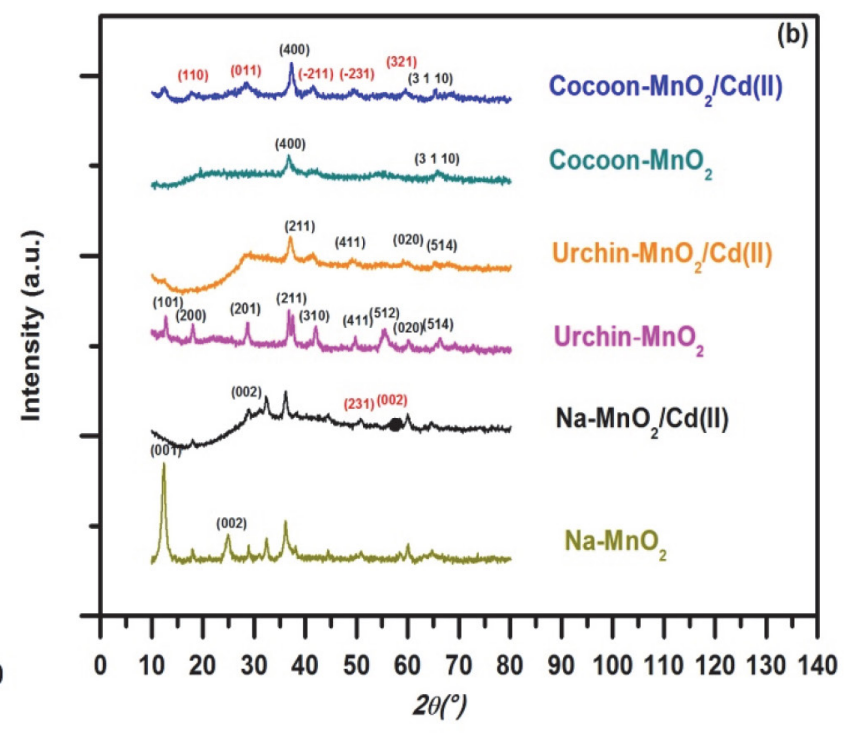

Figure 9. X-ray diffractograms of manganese oxides before and after interaction with (a) $\mathrm{Pb}$ (II) and (b) $\mathrm{Cd}(\mathrm{II})$. 
Table 4. Crystallographic parameters of the structures formed after interaction of $\mathrm{Pb}(\mathrm{II})$ and $\mathrm{Cd}(\mathrm{II})$ ions with the materials.

\begin{tabular}{|c|c|c|c|}
\hline & Phases formed & Mesh parameter $(\AA)$ & Crystal system \\
\hline $\begin{array}{c}\mathrm{Na}-\mathrm{MnO}_{2} \\
\text { (Before interaction) }\end{array}$ & $\begin{array}{c}\mathrm{Na}_{0.55} \mathrm{Mn}_{2} \mathrm{O}_{4} \cdot\left(\mathrm{H}_{2} \mathrm{O}\right)_{1.5} \\
\text { (Birnessite) }\end{array}$ & $\begin{array}{l}a=5.1750 \\
b=2.8490 \\
c=7.3380\end{array}$ & Monoclinic \\
\hline \multirow{2}{*}{$\begin{array}{c}\mathrm{Na}-\mathrm{MnO}_{2} \\
\text { (After interaction: } \mathrm{Pb}(\mathrm{II}) \text { ) }\end{array}$} & $\mathrm{PbO}$ & $\begin{array}{l}a=3.9744 \\
b=3.9744 \\
c=5.0220\end{array}$ & Tetragonal \\
\hline & $\begin{array}{c}\mathrm{Na}_{0.55} \mathrm{Mn}_{2} \mathrm{O}_{4} \cdot\left(\mathrm{H}_{2} \mathrm{O}\right)_{1.5} \\
\text { (Birnessite) }\end{array}$ & $\begin{array}{l}a=5.1750 \\
b=2.8490 \\
c=7.3380\end{array}$ & Monoclinic \\
\hline \multirow{2}{*}{$\begin{array}{c}\mathrm{Na}-\mathrm{MnO}_{2} \\
\text { (After interaction: } \mathrm{Cd}(\mathrm{II}) \text { ) }\end{array}$} & $\mathrm{Cd}(\mathrm{OH})_{2}$ & $\begin{array}{l}a=5.6700 \\
b=10.2500 \\
c=3.4100\end{array}$ & Monoclinic \\
\hline & $\begin{array}{c}\mathrm{Na}_{0.55} \mathrm{Mn}_{2} \mathrm{O}_{4} \cdot\left(\mathrm{H}_{2} \mathrm{O}\right)_{1.5} \\
\text { (Birnessite) }\end{array}$ & $\begin{array}{l}a=5.1750 \\
b=2.8490 \\
c=7.3380\end{array}$ & Monoclinic \\
\hline $\begin{array}{c}\text { Urchin- } \mathrm{MnO}_{2} \\
\text { (Before interaction) }\end{array}$ & $\begin{array}{c}\mathrm{KMn}_{8} \mathrm{O}_{16} \\
\text { (Cryptomelane) }\end{array}$ & $\begin{array}{l}a=b=9.840 \\
c=2.850\end{array}$ & Tetragonal \\
\hline \multirow{2}{*}{$\begin{array}{c}\text { Urchin- } \mathrm{MnO}_{2} \\
\text { (After interaction: } \mathrm{Pb}(\mathrm{II}) \text { ) }\end{array}$} & $\mathrm{Pb}_{2} \mathrm{Mn}_{8} \mathrm{O}_{16}$ & $\begin{array}{l}a=b=9.8900 \\
c=2.8620\end{array}$ & Tetragonal \\
\hline & $\begin{array}{c}\mathrm{KMn}_{8} \mathrm{O}_{16} \\
\text { (Cryptomelane) }\end{array}$ & $\begin{array}{l}\mathrm{a}=\mathrm{b}=9.840 \\
\mathrm{c}=2.850\end{array}$ & Tetragonal \\
\hline \multirow{2}{*}{$\begin{array}{c}\text { Urchin- } \mathrm{MnO}_{2} \\
\text { (After interaction: } \mathrm{Cd}(\mathrm{II}) \text { ) }\end{array}$} & $\mathrm{Cd}(\mathrm{OH})_{2}$ & $\begin{array}{l}a=5.6700 \\
b=10.2500 \\
c=3.4100\end{array}$ & Monoclinic \\
\hline & $\begin{array}{c}\mathrm{KMn}_{8} \mathrm{O}_{16} \\
\text { (Cryptomelane) }\end{array}$ & $\begin{array}{l}\mathrm{a}=\mathrm{b}=9.840 \\
\mathrm{c}=2.850\end{array}$ & Tetragonal \\
\hline $\begin{array}{c}\text { Cocoon- } \mathrm{MnO}_{2} \\
\text { (Before interaction) }\end{array}$ & $\mathrm{K}_{2} \mathrm{Mn}_{4} \mathrm{O}_{9}$ & $\begin{array}{l}a=b=11.2950 \\
c=21.870\end{array}$ & Hexagonal \\
\hline \multirow{2}{*}{$\begin{array}{c}\text { Urchin- } \mathrm{MnO}_{2} \\
\text { (After interaction: } \mathrm{Cd}(\mathrm{II}) \text { ) }\end{array}$} & $\mathrm{Pb}_{2} \mathrm{MnO}_{4}$ & $\begin{array}{l}a=b=12.7700 \\
c=5.1300\end{array}$ & Tetragonal \\
\hline & $\mathrm{K}_{2} \mathrm{Mn}_{4} \mathrm{O}_{9}$ & $\begin{array}{l}a=b=11.2950 \\
c=21.870\end{array}$ & Hexagonal \\
\hline \multirow{2}{*}{$\begin{array}{c}\text { Cocoon- } \mathrm{MnO}_{2} \\
\text { (After interaction: } \mathrm{Cd}(\mathrm{II}) \text { ) }\end{array}$} & $\mathrm{Cd}(\mathrm{OH})_{2}$ & $\begin{array}{l}a=5.6700 \\
b=10.2500 \\
c=3.4100\end{array}$ & Monoclinic \\
\hline & $\mathrm{K}_{2} \mathrm{Mn}_{4} \mathrm{O}_{9}$ & $\begin{array}{l}a=b=11.2950 \\
c=21.870\end{array}$ & Hexagonal \\
\hline
\end{tabular}

tification of the phases formed for the nanostructured material Urchin- $\mathrm{MnO}_{2}$ after interaction with $\mathrm{Pb}$ (II) ions (Figure $9 \mathrm{a}$ ) and $\mathrm{Cd}(\mathrm{II})$ ions (Figure $9 \mathrm{~b}$ ), showed the existence of the characteristic phase $\left(\mathrm{KMn}_{8} \mathrm{O}_{16}\right)$ of Urchin- $\mathrm{MnO}_{2}$ with the occurrence of $\mathrm{Pb}_{2} \mathrm{Mn}_{8} \mathrm{O}_{16}$ and $\mathrm{Cd}(\mathrm{OH})_{2}$ (Table 4). For Cocoon- $\mathrm{MnO}_{2}$, the characteristic phase of this material still existed with the formation of the $\mathrm{Pb}_{2} \mathrm{MnO}_{4}$ phase (Table 4) in the case of interaction with $\mathrm{Pb}(\mathrm{II})$ ions (Figure 9 a) and $\mathrm{Cd}(\mathrm{OH})_{2}$ in the case of
Cd(II) (Figure $9 \mathrm{~b}$ ). All diffractograms of the materials after interaction showed that the intensity of some peaks decreased while others disappeared. This deformation was due to the insertion of metal cations in the vacant octahedral sites and in the interlayer space between the $\mathrm{MnO}_{6}$ layers (case of $\mathrm{Na}-\mathrm{MnO}_{2}$ ) or in the cavities (case of Urchin- $\mathrm{MnO}_{2}$ and Cocoon- $\mathrm{MnO}_{2}$ ) which created a disorder in the materials. ${ }^{27}$ Based on the results obtained, it could be said that the removal of metal ions after interac- 
tion with the materials was achieved either by insertion as $\mathrm{MO}$ oxide $(\mathrm{PbO})$ or by adsorption as $\mathrm{M}(\mathrm{OH})_{2}$ hydroxide $\left(\mathrm{Cd}(\mathrm{OH})_{2}\right)$ or by the formation of new phases such as $\mathrm{Pb}_{2} \mathrm{MnO}_{4}$ and $\mathrm{Pb}_{2} \mathrm{Mn}_{8} \mathrm{O}_{16}$. As shown, subsequent studies reported that the analysis of materials after interaction with $\mathrm{Cd}(\mathrm{II})$ ions by $\mathrm{X}$-ray photoelectron spectroscopy (XPS) showed that $\mathrm{Cd}$ (II) was adsorbed on $\mathrm{MnO}_{2}$ as $\mathrm{CdO}$ and $\mathrm{Cd}(\mathrm{OH})_{2} \cdot{ }^{27}$

\section{Stability and Reusability of the $\mathrm{Na}-\mathrm{MnO}_{2}$}

In this study, the lamellar material $\mathrm{Na}-\mathrm{MnO}_{2}$ showed the highest removal efficiency of metal ions at different $\mathrm{pH}$ values, a high removal capacity as well as a very high stability compared to nanostructured materials. In this context, the reusability of this material for the removal of $\mathrm{Pb}$ (II) and $\mathrm{Cd}(\mathrm{II})$ ions was studied. Five successive adsorption cycles were investigated. After each cycle, the nanomaterial $\mathrm{Na}-\mathrm{MnO}_{2}$ was recovered by filtration, washed with water and dried, it was used in the subsequent cycle. As shown in Figure 10, the nanomaterial $\mathrm{Na}-\mathrm{MnO}_{2}$ could remove $97.26 \% \mathrm{~Pb}(\mathrm{II})$ and $97.44 \% \mathrm{Cd}(\mathrm{II})$ in the initial cycle. A gradual decrease in removal efficiencies from 97.26 $\%$ to $78.05 \%$ and $97.44 \%$ to $69 \%$ were observed after five reuses for $\mathrm{Pb}(\mathrm{II})$ and $\mathrm{Cd}(\mathrm{II})$ respectively. It was clear that the reusable capability of the nanomaterial $\mathrm{Na}-\mathrm{MnO}_{2}$ decreased slightly with an increase in the number of cycles. But in general, $\mathrm{Na}-\mathrm{MnO}_{2}$ was maintained at a relatively high removal efficiency.

The slight decrease in heavy metal removal efficiency could be due to the dissolution or release of a low concentration of manganese ions and the change in morphology of the material by reducing its available active sites. Simul-

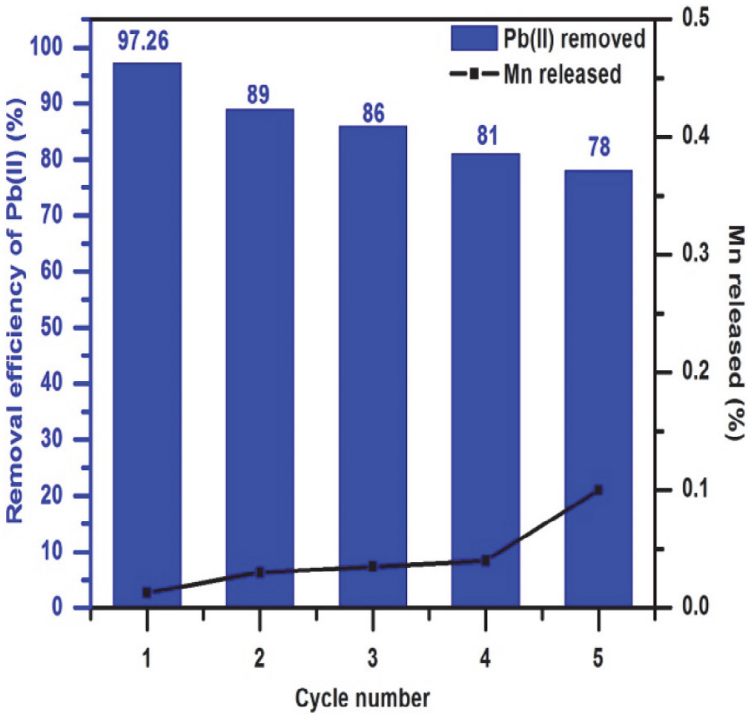

taneously, AAS was employed to measure Mn concentration in the solution after each cycle (Figure 10, black line). Therefore, after 5 cycles of use the percentage of $\mathrm{Mn}$ released from the material was less than $0.1 \%$ and $0.48 \%$ in the case of $\mathrm{Pb}(\mathrm{II})$ and $\mathrm{Cd}(\mathrm{II})$ respectively, indicating good stability of $\mathrm{Na}-\mathrm{MnO}_{2}$.

\section{Conclusions}

XRD and SEM analysis showed that the prepared manganese oxides: $\mathrm{Na}-\mathrm{MnO}_{2}$, Urchin- $\mathrm{MnO}_{2}$, and Cocoon- $\mathrm{MnO}_{2}$ were composed of a monophase characteristic of each structure elaborated, these oxides had particular morphologies. Studies of adsorption/desorption of $\mathrm{N}_{2}$ of the materials showed that their structures were composed of a mixture of pores with a predominance of mesopores of more than $53 \%$ of the total porous surface. This study showed that structure and morphology had a direct effect on the elimination of metal cations $\mathrm{Pb}$ (II) and $\mathrm{Cd}(\mathrm{II})$. All materials (lamellar: $\mathrm{Na}-\mathrm{MnO}_{2}$ and nanostructures: Urchin- $\mathrm{MnO}_{2}$ and Cocoon- $\mathrm{MnO}_{2}$ ) showed a high reactivity towards both metals with a high yield of more than $90 \%$ for a very short duration (less than 15 minutes) at free $\mathrm{pH}$ (6.5). These materials also demonstrated high stability during the removal process. In the case of the $\mathrm{Na}-\mathrm{MnO}_{2}$ lamellar material, the removal efficiency of metal cations was very high above $99 \%$, and the release rates of manganese were lower than $0.4 \%$. The reusability of the lamellar material $\mathrm{Na}-\mathrm{MnO}_{2}$ showed that it could be used more than 5 cycles without loss of performance and stability. The lamellar material $\mathrm{Na}-\mathrm{MnO}_{2}$ was very efficient, had a high removal capacity was very stable and suitable for several uses for the removal of metal ions.

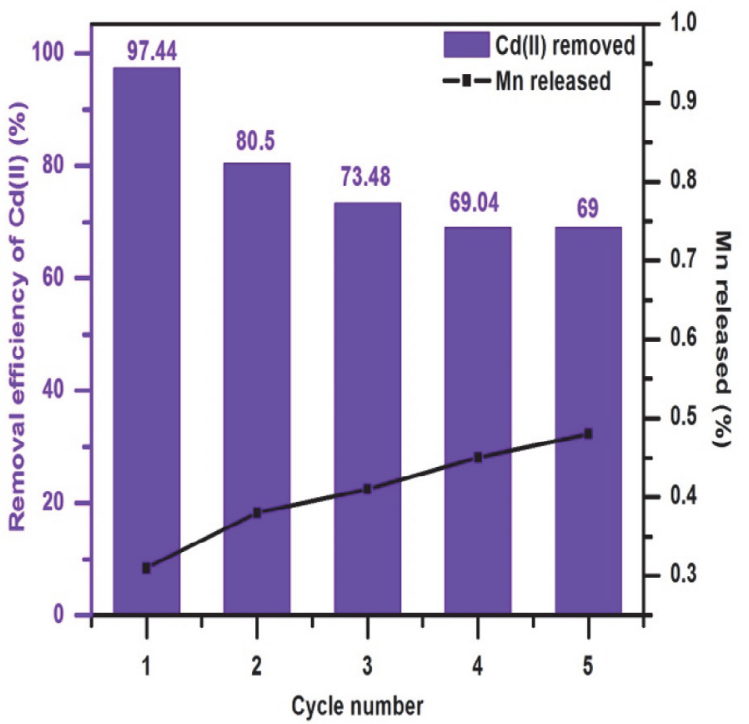

Figure 10. Stability and reusability of $\mathrm{Na}-\mathrm{MnO}_{2}$ to remove $\mathrm{Pb}(\mathrm{II})$ and $\mathrm{Cd}(\mathrm{II})$ (Conditions: initial concentration of metal ions= $30 \mathrm{ppm}, \mathrm{t}=30 \mathrm{~min}$ for each cycle). 


\section{Supporting Information}

The equation (S1), pore size distributions of three $\mathrm{MnO}_{2}$ (lamellar and nanostructures), comparative study of $\mathrm{Cd}(\mathrm{II})$ and $\mathrm{Pb}(\mathrm{II})$ removal efficiencies. Langmuir isotherm plot for $\mathrm{Pb}(\mathrm{II})$ and $\mathrm{Cd}(\mathrm{II})$ adsorption, Amount of $\mathrm{Na}^{+}$released during the removal of $\mathrm{Pb}(\mathrm{II})$, and $\mathrm{Cd}(\mathrm{II})$ ions by $\mathrm{Na}$ $\mathrm{MnO}_{2}$. Amount of $\mathrm{K}^{+}$released during the removal of $\mathrm{Pb}$ (II) and $\mathrm{Cd}(\mathrm{II})$ ions by Urchin- $\mathrm{MnO}_{2}$ and Cocoon- $\mathrm{MnO}_{2}$. Porous structure parameters of each material, Adsorption coefficients of $\mathrm{Pb}$ (II) and $\mathrm{Cd}(\mathrm{II})$ of the pseudo-first-order and pseudo-second-order models. Isotherm parameters for Langmuir, Freundlich, and Temkin models.

\section{Acknowledgments}

The authors warmly thank the OCP (Office Chérifien des Phosphates), R\&D Foundation (Research and Development) for the financial support of this project $\mathrm{Na}-$ tional Centre for Scientific and Technical Research (CNRST), Ministry of Higher Education Scientific Research.

\section{Conflicts of Interest}

The authors declare no conflict of interest.

\section{References}

1. A. S. Ertürk, M. U. Gürbüz, M. Tülü, A.E. Bozdoğan, J. Acta Chim. Slov. 2018, 65, 65-74. DOI:10.17344/acsi.2017.3485

2. S. Sharma, A. K. Nagpal, I. Kaur, J. Chemosphere. 2019, 227, 179-190. DOI:10.1016/j.chemosphere.2019.04.009

3. A. Karimi, A. Naghizadeh, H. Biglari, R. Peirovi, A. Ghasemi, A. Zarei, J. Environ. Sci. Pollut. Res. 2020, 27, 10317-10327. DOI:10.1007/s11356-020-07642-6

4. D. Humelnicu, L.V. Soroaga, C. Arsene, I. Humelnicu, R.I. Olariu, J. Acta Chim. Slov. 2019, 66, 326-336.

DOI:10.17344/acsi.2018.4821

5. S. Z. Ahmad Nurain, W. N. Wan Salleh, A. Fauzi Ismail, N. Yusof, M. Z. M. Yusop, F. Aziz, J. Chemosphere. 2020, 248, 1-16. DOI:10.1016/j.chemosphere.2020.126008

6. F. Alshahri, J. Environ. Sci. Pollut. Res. 2016, 24, 1821-1831. DOI:10.1007/s11356-016-7961-x

7. S.M. Mousavi, S.A. Hashemi, H. Esmaeili, A.M. Amani, F. Mojoudi, J. Acta Chim. Slov. 2018, 65, 750-756.

DOI:10.17344/acsi.2018.4536

8. X. Xu, Y. Yang, G. Wang, S. Zhang, Z. Cheng, T. Li, Z. Yang, J. Xian, Y. Yang, W. Zhou, J. Chemosphere. 2020, 246, 125816. DOI:10.1016/j.chemosphere.2020.125816

9. J. Xue, Y. Zhi, L. Y. Wu, J. Shi, L. Zeng, L. Wu, J. Env. Sci Pollut Res. 2014, 21, 7698-7707. DOI:10.1007/s11356-014-2726-x

10. C. Lee, T. Kim, S. Komarneni, S. Han,Y. Cho, J. Appl. Clay Sci. 2013, 83-84, 263-269. DOI:10.1016/j.clay.2013.08.035

11. G. Zheng, L. Tian, Y. Liang, K. Broberg, L. Lei, W. Guo, J. Nilsson, I. A. Bergdahl, S. Skerfving, T. Jin, J. Neurotoxicology.
2011, 32, 374-382. DOI:10.1016/j.neuro.2011.03.006

12. P. Aendo, S. Thongyuan, T. Songserm, P. Tulayakul, J. Sci. Total Environ. 2019, 689, 215-222.

DOI:10.1016/j.scitotenv.2019.06.414

13. T. Shah, F. Munsif, D. Roberto, L. Nie, J. Chemosphere. 2019, 246, 125766. DOI:10.1016/j.chemosphere.2019.125766

14. B. Nunes, R. C. Capela, T. Sérgio, C. Caldeira, F. Gonçalves, A. T. Correia, J. Env. Sci Pollut Res. 2014, 21, 5689-5700. DOI:10.1007/s11356-013-2485-0

15. C. M. Liu, J.-Q. Ma, Y.-Z. Sun, J. Environ. Toxicol. Pharmacol. 2010, 30, 264-271. DOI:10.1016/j.etap.2010.07.002

16. N. D. Bustamante, W. L. Macias-konstantopoulos, J. Emerg. Med. 2016, 51, 45-49. DOI:10.1016/j.jemermed.2016.02.025

17. P. Chen, X. Duan, M. Li, C. Huang, J. Li, R. Chu, H. Ying, H. Song, X. Jia, Q. Ba, H. Wang, J. Toxicol. Appl. Pharmacol. 2016, 310, 150-158. DOI:10.1016/j.taap.2016.09.006

18. F. Fu, Q. Wang, J. Environ. Manage. 2011, 92, 407-418. DOI:10.1016/j.jenvman.2010.11.011

19. P. Zhang, S. Ouyang, P. Li, Z. Sun, N. Ding, Y. Huang, J. Clean. Prod. 2019, 246, 118728. DOI:10.1016/j.jclepro.2019.118728

20. S. Hu, F. Lian, J. Wang, J. Sci. Total Environ. 2019, 666, $956-$ 963. DOI:10.1016/j.scitotenv.2019.02.285

21. P. Caecilia, S. Ketut, N. Yustina, H. Prasetyo, J. Matec Web Conf. 2016, 58, 10-13. DOI: $10.1051 /$ matec conf/20165801022

22. F. Scholz, H. Kahlert, J. ChemTexts, 2015, 7, 1-9. DOI:10.1007/s40828-015-0006-0

23. J. Kheriji, D. Tabassi, B. Hamrouni, J. Water Sci. Technol. 2015, 7, 1206-1216. DOI:10.2166/wst.2015.326

24. A. El-Gendi, S. Ali, H. Abdalla, M. Saied, J. Memb.Wat. Tre. 2016, 7, 55-70. DOI:10.12989/mwt.2016.7.1.055

25. S. M. Shaheen, A. S. Derbalah and F. S. Moghanm, J. Environ. Sci. Dev. 2012, 3, 362-367. DOI:10.7763/IJESD.2012.V3.248

26. M. Araissi, I. Ayed, E. Elaloui, Y. Moussaoui, J. Water Sci. Technol. 2016, 73, 1628-1636. DOI:10.2166/wst.2015.640

27. L. Peng, Q. Zeng, B. Tie, M. Lei, J. Yang, S. Luo, Z. Song, J. Colloid interface Sci. 2015, 456, 108-115.

DOI:10.1016/j.jcis.2015.06.017

28. Y. Cho, S. Jang, Y. Kim, S. Komarneni, S. Kim, J. Porous Mater. 2011, 18, 125-131. DOI:10.1007/s10934-010-9430-0

29. N. N. Nassar, J. Hazard. Mater. 2010, 184, 538-546. DOI:10.1016/j.jhazmat.2010.08.069

30. H. N. Trana, D. T. Nguyenb, G. T. Le, F. Tomul, E. C. Lima, S. H. Woo, A. K. Sarmah, H. Q. Nguyen, P. T. Nguyen, D. D. Nguyen, T. V. N. S. Vigneswaran, N. V. Dai-Viet, H.-P. Chaol, J. Hazard. Mater. 2019, 373, 258-270. DOI:10.1016/j.jhazmat.2019.03.018

31. A. Avram, T. Frentiu, O. Horovitz, A. Mocanu, F. Goga, M. Tomoaia-cotisel, J. Stud. Ubb Chem. 2017, 4, 93-104. DOI: $10.24193 /$ subbchem.2017.4.08

32. A. A. Hanna, M. A. Sherief, R. M. Aboelenin, S. M. Mousa, Can. J. Pure Appl. Sci. 2010, 4, 1087-1093.

J. Pure Appl. Sci. 2010, 4, 1087-1093.

33. M. Torab-Mostaedi, H. Ghassabzadeh, M. Ghannadi-Maragheh, S. J. Ahmadi, H. Taheri, Brazilian J. Chem. Eng. 2010, 27, 299-308. DOI:10.1590/S0104-66322010000200008 34. N. Mohamad, I. Abustan, M. Mohamad, K. Samuding, J. Ma- 
ter. Today Proc. 2018, 5, 21832-21840.

DOI:10.1016/j.matpr.2018.07.039

35. S. Deng, X. Liu, J. Liao, H. Lin, F. Liu, J. Chem. Eng. 2019, 375, 122086. DOI:10.1016/j.cej.2019.122086

36. M. Hojamberdiev, S. S. Daminova, Z. C. Kadirova, K. T. Sharipov, F. Mtalo, M. Hasegawa, J. Environ. Chem. Eng. 2018, 6, 4623-4633. DOI:10.1016/j.jece.2018.06.070

37. H. Vojoudi, A. Badiei, S. Bahar, G. M. Ziarani, F. Faridbod, M. R. Ganjali, J. Magn. Magn. Mater. 2017, 441, 193-203. DOI:10.1016/j.jmmm.2017.05.065

38. S. Mnasri-ghnimi, N. Frini-srasra, J. Appl. Clay Sci. 2019, 179, 1-17. DOI:10.1016/j.clay.2019.105151

39. A. Djukic, U. Jovanovic, T. Tuvic, V. Andric, J. Novakovic Grbovic, N. Ivanovic, L. Matovic, J. Ceram. Int. 2013, 39, 71737178. DOI:10.1016/j.ceramint.2013.02.061

40. N. M. Mubarak, J. N. Sahu, E. C. Abdullah and N. S. Jayakumar, J. Sep. Purif. Rev. 2014, 43, 37-41.

DOI: $10.1080 / 15422119.2013 .821996$

41. J. H. Potgieter, S. S. Potgieter-Vermaak and P. D. Kalibantonga, J. Miner. Eng. 2006, 19, 463-470.

DOI:10.1016/j.mineng.2005.07.004

42. A. Afkhami, M. Saber-tehrani and H. Bagheri, J. Hazard. Mater. 2010, 181, 836-844. DOI:10.1016/j.jhazmat.2010.05.089

43. D. Sofronov, A. Krasnopyorova, N. Efimova, A. Oreshina, E. Bryleva, G. Yuhno, S. Lavrynenko, M. Rucki, J. Process Saf. Environ. Prot. 2019, 125, 157-163.

DOI:10.1016/j.psep.2019.03.013

44. S. Hoseini, N. Rahemi, S. Allahyari, M. Tasbihi, J. Clean. Prod. 2019, 232, 1134-1147. DOI:10.1016/j.jclepro.2019.05.227

45. A. M. Muliwa, M. S. Onyango, A. Maity, A. Ochieng, Int. J. Environ. Sci. Technol. 2018, 16, 2895-2904.

DOI:10.1007/s13762-018-1817-5

46. L. Liu, Q. Peng, G. Qiu, J. Zhu, W. Tan, C. Liu, L. Zheng, Z. Dang, J. Environ. Pollut. 2019, 244, 783-791.

DOI:10.1016/j.envpol.2018.10.062

47. W. Zhao, X. Feng, W. Tan, F. Liu, S. Ding, J. Environ. Sci. 2009, 21, 520-526. DOI:10.1016/S1001-0742(08)62302-5

48. P. Yang, E. Post, Q. Wang, W. Xu, R. Geiss, P. R. Mccurdy, M. Zhu, J. Environ. Sci. Technol. 2019, 53, 7453-7462.

DOI:10.1021/acs.est.9b01242

49. Y. Wang, X. Feng, M. Villalobos, W. Tan, F. Liu, J. Chem. Geol. 2012, 292-293, 25-34. DOI:10.1016/j.chemgeo.2011.11.001

50. H. Antoni, D. M. Morales, J. Bitzer, Q. Fu, Y. Chen, J. Masa, W. Kleist, W. Schuhmann, M. Muhler, J. Catalysis. 2019, 374, 335-344. DOI:10.1016/j.jcat.2019.05.010

51. H. M. Abuzeid, S. A. Elsherif, N. A. Abdelghany, A. M. Hashem, J. Energy Storage. 2019, 21, 156-162.

DOI:10.1016/j.est.2018.11.021

52. S. Garcia, S. Sardar, S. Maldonado, V. Garcia, C. Tamez, J. G. Parsons, J. Microchemical. 2014, 117, 52-60.

DOI:10.1016/j.microc.2014.06.008

53. M. H. Salmani, M. Vakili, M. H. Ehrampoush, J. Toxicol. Environ. Health Sci. 2013, 5, 150-155.

DOI:10.5897/JTEHS2013.0275

54. N. N. Nassar, Can. J. Chem. Eng. 2012, 90, 1231-1238. DOI:10.1002/cjce.20613
55. D. C. Ong, S. M. B. Pingul-ong, C. Kan, M. Daniel, G. De Luna, J. Clean. Prod. 2018, 190, 443-451.

DOI:10.1016/j.jclepro.2018.04.175

56. S. Rahimi, R. M. Moattari, L. Rajabi, A. Ashraf, M. Keyhani, J. Ind. Eng. Chem. 2015, 23, 33-43.

DOI:10.1016/j.jiec.2014.07.039

57. G. Tan, Y. Liu, D. Xiao, Carbohydr. Polym. 2019, 219, 306-315. DOI:10.1016/j.carbpol.2019.04.058

58. Q. Su, B. Pan, S. Wan, W. Zhang, L. Lv, J. Colloid Interface Sci. 2010, 349, 607-612. DOI:10.1016/j.jcis.2010.05.052

59. R. M. Mckenzie, Aust. J. Soil Res. 1980, 18, 61-73. DOI:10.1071/SR9800061

60. H. Zhang, F. Xu, J. Xue, S. Chen and J. Wang, J. Sci. Rep. 2020, 10, 6067-6079. DOI:10.1038/s41598-020-63000-Z

61. E. S. A. Nouh, J. Environ. Anal. Chem. 2020, 00, 1-14. DOI: $10.1080 / 03067319.2020 .1751834$

62. E. S. A. Nouh, M. Amin, M. Gouda and A. Abd-elmagid, J. Biochem. Pharmacol. 2015, 3, 523-528.

DOI:10.1016/j.jece.2015.01.013

63. Q. Nan, C. Hong, Y. Zhaoming, S. Sen, W. Yuan, J. Electrochim. Acta. 2018, 272, 154-160.

DOI: $10.1016 /$ j.electacta.2018.04.012

64. X. Yu, J. He, D. Wang, Y. Hu, H. Tian, Z. He, J. Phys. Chem. C. 2012, 116, 851-860. DOI:10.1021/jp208947e

65. Q. Peng, L. Liu, Y. Luo, Y. Zhang, W. Tan, F. Liu, S. L. Suib, G. Qiu, J. Appl. Matererials Interfaces. 2016, 50, 34405-34413. DOI:10.1021/acsami.6b12224

66. H. Boumaiza, A. Renard, M. R. Robinson, L. Vidal, C. Ruby, L. Bergaoui, R. Coustel, J. Solid State Chem. 2019, 272, 234-243. DOI:10.1016/j.jssc.2019.02.017

67. C. M. Julien and A. Mauger, J. Nanomaterials. 2017, 7, 396437. DOI:10.3390/nano7110396

68. H. Lin, D. Chen, H. Liu, X. Zou, T. Chen, J. Aerosol Air Qual. Res. 2017, 17, 1011-1020. DOI:10.4209/aaqr.2017.01.0013

69. A. S. Poyraz, J. Huang, C. J. Pelliccione, X. Tong, S. Cheng, L. Wu, Y. Zhu, A. C. Marschilok, K. J. Takeuchi, E. S. Takeuchi, J. Mater. Chem. A. 2017, 5, 16914-16928.

DOI:10.1039/C7TA03476H

70. Y. R. Li, A. C. Marschilok, E. S. Takeuchi, K. J. Takeuchi, J. Electrochem. Soc. 2016, 163, A281-A285.

DOI:10.1149/2.0501602jes

71. H. Gao, I. D. Seymour, S. Xin, L. Xue, G. Henkelman, J. B. Goodenough, J. Am. Chem. Soc. 2018, 140, 18192-18199. DOI:10.1021/jacs.8b11388

72. G. Zoua, B. Gea, H. Zhanga, Q. Zhangb, C. Fernandezc, W. Lid, J. Huanga, Q. Peng, J. Mater. Chem. A. 2019, 6, 30913101. DOI: 10.1039/C9TA00744J

73. C. Yuan, B. Gao, L. Su, X. Zhang, J. Colloid Interface Sci. 2008, 322, 545-550. DOI:10.1016/j.jcis.2008.02.055

74. T. Mathialagan, T. Viraraghavan, J. Hazard. Mater. 2006, B134, 257-267. DOI: 10.1016/j.jhazmat.2005.11.052

75. S. Wan, J. Wu, S. Zhou, R. Wang, B. Gao and F. He, J. Sci. Total Environ. 2018, 616, 1298-1306. DOI:10.1016/j.scitotenv.2017.10.188

76. K. D. Kwon, K. Refson, G. Sposito, J. Geochim. Cosmochim. Acta. 2010, 23, 6731-6740. DOI: 10.1016/j.gca.2010.09.002 
77. L. Della Puppa, F. Bordas, M. Komárek, J. Bollinger, E. Joussein, J. Colloid Interface Sci. 2013, 399, 99-106.

DOI:10.1016/j.jcis.2013.02.029

78. X. H. Feng, L. M. Zhai, W. F. Tan, F. Liu, J. Z. He, J. Environ. Pollut. 2007, 147, 366-373.

DOI:10.1016/j.envpol.2006.05.028

79. K. Parida, P. K. Satapathy, N. DAS, J. Colloid Interface Sci. 1996, 181, 456-462. DOI:10.1006/jcis.1996.0402

80. L. Liu, G. Qiu, S. L. Suib, F. Liu, L. Zhen, W. Tan, L. Qin, J. Chem. Eng. 2017, 328, 464-473.

DOI:10.1016/j.cej.2017.07.066

81. R. Han, W. Zou, Z. Zhang, J. Shi and J. Yang, J. Hazard. Mater. 2006, 137, 384-395. DOI:10.1016/j.jhazmat.2006.02.021

82. Q. Kang, L. Vernisse, R. C. Remsing, A. C. Thenuwara, S. L. Shumlas, I. G. McKendry, M. L. Klein, E. Borguet, M. J. Zdilla, D. R. Strongin, J. Am. Chem. Soc. 2017, 139, 1863-1870. DOI:10.1021/jacs.6b09184

83. D. Robati, J. Nanostructure Chem. 2013, 3, 55-60. DOI:10.1186/2193-8865-3-55

84. D. Sidiras, F. Batzias, E. Schroeder, R. Ranjan, M. Tsapatsis, J. Chem. Eng. 2011, 171, 883-896.

DOI:10.1016/j.cej.2011.04.029
85. E. Eren, H. Gumus and A. Sarihan, J. Desalination. 2011, 279, 75-85. DOI:10.1016/j.desal.2011.05.058

86. Y. Huang, C. Hsueh, C. Huang, L. Su and C. Chen, J. Sep. Purif. Technol. 2007, 55, 23-29.

DOI:10.1016/j.seppur.2006.10.023

87. S. Recillas, A. García, E. González, E. Casals, V. Puntes, A. Sánchez and X. Font, J. Desalination. 2011, 277, 213-220. DOI:10.1016/j.desal.2011.04.036

88. C. Andrea, C. Rosas, M. Franzreb, F. Valenzuela and W. H. Höll, J. React. Funct. Polym. 2010, 70, 516-520.

DOI:10.1016/j.reactfunctpolym.2010.03.011

89. E.Alvarez-Ayuso, A. Garcia-Sàncheza and X. Querol, J. Water Res. 2003, 37, 4855-4862.

DOI:10.1016/j.watres.2003.08.009

90. J. R. Rangel-Mendez and M. Streat, J. Water Res. 36. 2002, 36, 1244-1252. DOI:10.1016/S0043-1354(01)00343-8

91. M. J. Young, A. M. Holder, S. M. George, C. B. Musgrave, J. Chem. Mater. 2015, 27, 1172-1180.

DOI:10.1021/cm503544e

92. H. Li, F. Liu, M. Zhu, X. Feng, J. Zhang, H. Yin, J. Environ. Sci. 2015, 34, 77-85. DOI:10.1016/j.jes.2015.02.006

\section{Povzetek}

Z netoksičnimi metodami smo sintetizirali lamelarne in nanostrukturirane manganove okside. Materiali so bili enofazni z značilnimi morfologijami in pretežno mezoporozno strukturo. Preučevali smo možnosti odstranjevanja težkih kovin $\mathrm{Cd}\left(\mathrm{II}\right.$ ) in $\mathrm{Pb}$ (II) s sintetiziranimi materiali $\mathrm{Na}-\mathrm{MnO}_{2}, \mathrm{u}-\mathrm{MnO}_{2}$ (v obliki morskih ježkov) in c- $\mathrm{MnO}_{2}$ (v obliki zapredkov). $\mathrm{Z}$ vidika kinetike je bil najučinkovitejši od treh preizkušenih materialov lamelarni $\mathrm{Na}-\mathrm{MnO}_{2}$ ki ima več praznin v plasteh $\mathrm{MnO}_{6}$ kot tudi med posameznimi plastmi. Nanomateriala $\mathrm{u}-\mathrm{MnO}_{2}$ in c- $\mathrm{MnO}_{2}$ sta izmenjevala katione $\mathrm{v}$ tunelih in vdolbinah. Maksimalne adsorbirane količine so si sledile $\mathrm{za} \mathrm{Pb}(\mathrm{II}): \mathrm{Na}-\mathrm{MnO}_{2}(297 \mathrm{mg} / \mathrm{g})>\mathrm{u}-\mathrm{MnO}_{2}(264 \mathrm{mg} / \mathrm{g})>$

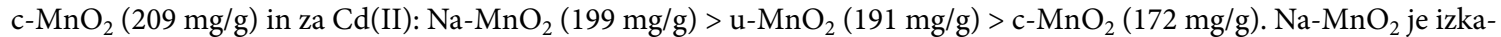
zoval najboljšo stabilnost med strukturami in sproščal le male količine mangana. Rezultati kažejo potencial lamelarnih $\left(\mathrm{Na} \cdot \mathrm{MnO}_{2}\right)$ in nanostrukturiranih $\left(\mathrm{U}-\mathrm{MnO}_{2}\right.$ in C- $\left.\mathrm{MnO}_{2}\right)$ manganovih oksidov kot selektivnih, ekonomičnih in stabilnih materialov za odstranjevanje toksičnih kovin v vodnem mediju.

Except when otherwise noted, articles in this journal are published under the terms and conditions of the Creative Commons Attribution 4.0 International License 